\title{
Cistanche Tubulosa Phenylethanoid Glycosides Induce Apoptosis of Hepatocellular Carcinoma Cells by Mitochondria-Dependent and MAPK Pathways and Enhance Antitumor Effect Through Combination With Cisplatin
}

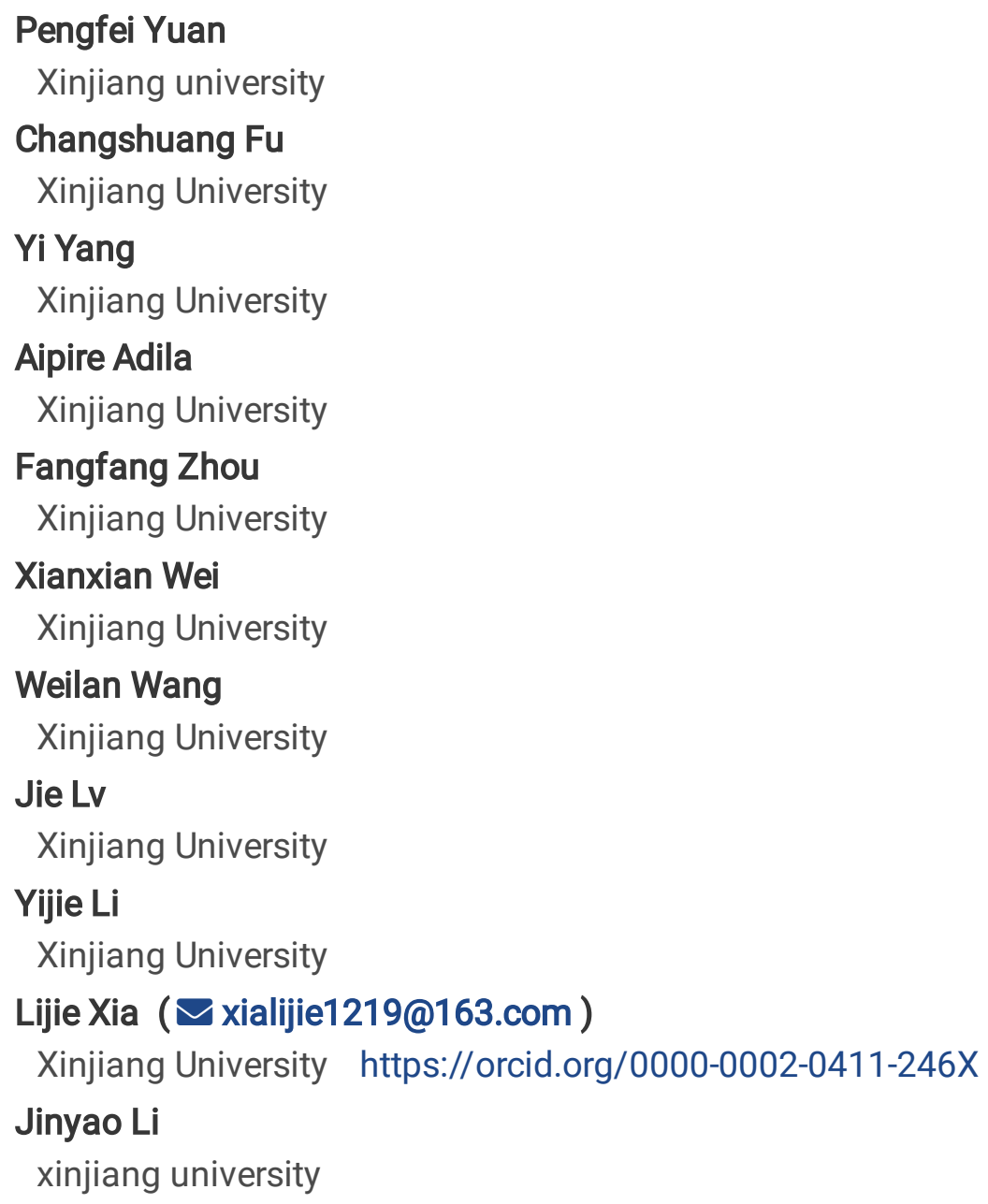

\section{Research}

Keywords: Cistanche tubulosa phenylethanoid glycosides, apoptosis, MAPK pathway, mitochondria-dependent pathway, immunoenhancement

Posted Date: January 5th, 2021

DOI: https://doi.org/10.21203/rs.3.rs-136218/v1 
License: (c) (i) This work is licensed under a Creative Commons Attribution 4.0 International License. Read Full License

Loading [MathJax]/jax/output/CommonHTML/fonts/TeX/fontdata.js

Page 2/25 


\section{Abstract}

Background

Previous studies have been demonstrated that Cistanche tubulosa phenylethanoid glycosides (CTPG) exhibit antitumor effects on a variety of tumor cells. However, the antitumor effects of CTPG on HepG2 and BEL-7404 hepatocellular carcinoma (HCC) cells are still elusive.

Results

Our study showed that CTPG significantly inhibited the growth of HepG2 and BEL-7404 cells through the induction of cell cycle arrest and apoptosis, which was associated with the activation of MAPK pathways characterized by the up-regulated phosphorylation of p38, JNK, and ERK1/2 and mitochondria-dependent pathway characterized by the reduction of mitochondrial membrane potential. The release of cytochrome $c$ and the cleavage of caspase-3, -7 , -9 and PARP were subsequently increased by CTPG treatment. Moreover, CTPG significantly suppressed the migration of HepG2 through reducing the levels of matrix metalloproteinase-2 and vascular endothelial growth factor. Interestingly, CTPG not only enhanced the proliferation of splenocytes but also reduced the apoptosis of splenocytes induced by cisplatin. In H22 tumor mouse model, CTPG combined with cisplatin further inhibited the growth of $\mathrm{H} 22$ cells and reduced the side effects of cisplatin.

Conclusion

Taken together, CTPG inhibited the growth of HCC through direct antitumor effect and indirect immunoenhancement effect, improved the antitumor efficacy of cisplatin.

\section{Introduction}

Liver cancer was predicted to be the sixth most commonly diagnosed cancer and the fourth leading cause of cancer death worldwide in 2018, with about 841,000 new cases and 782,000 deaths annually in South-Eastern Asia (Mongolia, Cambodia, and Vietnam) [1]. In China, liver cancer was the third leading cause of cancer-related death in 2015 [2]. More than $90 \%$ of primary liver cancers are hepatocellular carcinoma (HCC) throughout the world. Currently, hepatectomy, liver transplantation and percutaneous ablation are the main methods for the treatment of HCC. Unfortunately, these treatments are effective for patients diagnosed with early liver cancer accounting for $30 \%$ while patients diagnosed as advanced liver cancer (accounting for $40 \%$ ) have to rely on palliative treatment to extend their survival time [3, 4]. Solafinib in combination with hepatic arterial chemoembolism is an important and common palliative therapy for most patients with advanced HCC in the Asia-Pacific region [5]. Solafinib, approved by FAD in 2006 for the treatment of advanced liver cancer, is a multiple kinase inhibitor that inhibits tumor cell proliferation and vascular production and promotes tumor cell apoptosis. Solafinib significantly extends the patient's survival time by 3 to 5 months but has serious side effects and is closely related to the occurrence of drug resistance [6]. Therefore, it is urgent to develop new drugs or strategies for HCC.

Traditional Chinese medicine (TCM) alone or in combination with other strategies has been used to treat $\mathrm{HCC}$ and has shown clinical benefits including extended survival time, improved life quality, reduced adverse reactions, and so on [7, 8]. Cistanche is a TCM including phenylethanoid glycosides (PhGs), iridoids, lignin and polysaccharides which has various biological functions, such as anti-oxidation, anti-inflammation, anti-aging, memory enhancement and immune enhancement functions [9]. PhGs have been considered as the major active components of Cistanche, Loading [MathJax]/jax/output/CommonHTML/fonts/TeX/fontdata.js

Page $3 / 25$ 
which have multiple functions including anti-oxidation, anti-inflammation, anti-apoptosis, hepatoprotection and neuroprotection [10-12]. Our group had reported that Cistanche tubulosa phenylethanoid glycosides (CTPG) could inhibit the growth of melanoma B16-F10 cells, esophageal carcinoma Eca-109 cells and HCC H22 cells though extrinsic or intrinsic signaling pathways in vitro or in vivo, in addition, CTPG had immunostimulatory effect [13-15].

In this study, we investigated the antitumor effect and mechanism of CTPG on HepG2 and BEL-7404 cells in vitro, analyzed the immunomodulatory function of CTPG in vitro and in vivo, and further evaluated the therapeutic effect of CTPG combined with chemotherapy drug cisplatin on HCC H22 tumor mice in vivo. We found that CTPG could inhibit the growth of HepG2 and BEL-7404 cells through mitochondria-dependent apoptosis and MAPK signaling pathway. CTPG significantly inhibited the migration of HepG2 cells by reducing the levels of matrix metalloproteinase-2 (MMP-2) and vascular endothelial growth factor (VEGF). In addition, CTPG promoted the proliferation and activation of immune cells, and enhanced the immunity of mice. Importantly, CTPG combined with cisplatin can further inhibit the growth of $\mathrm{H} 22$ cells in vivo and reduced the side effects of cisplatin.

\section{Materials And Methods}

\section{Animals}

6-8 weeks of male BALB/c, Kunming mice and female C57BL/6 mice were purchased from Animal Laboratory Center, Xinjiang medical university (Urumqi, Xinjiang, China) and housed in an animal facility of Xinjiang University with the room temperature (RT) of $25 \pm 3^{\circ} \mathrm{C}$, and a $12 \mathrm{~h} / 12 \mathrm{~h}$ light-dark period.

\section{Cell lines and cell culture}

The murine H22 cells were purchased from Procell Life Science \& Technology Co., Ltd. (Wuhan, Hubei, china) and human HCC HepG2 and BEL-7404 cells were obtained from the Xinjiang Key Laboratory of Biological Resources and Genetic Engineering, Xinjiang University (Urumqi, Xinjiang, China) and cultured in RPMI 1640 medium (Gibco, USA) or Dulbeccos mod if iedEag $\leq$ s medium (DMED) (Gibco) containing $10 \%$ heat-inactivated fetal bovine serum (MRC, China), $1 \%$ Lglutamine $(100 \mathrm{mM}), 100 \mathrm{U} / \mathrm{mL}$ penicillin and $100 \mu \mathrm{g} / \mathrm{mL}$ streptomycin at $37^{\circ} \mathrm{C}$ in a humidified atmosphere of $5 \% \mathrm{CO}_{2}$.

\section{High performance liquid chromatography (HPLC)}

The major compounds of CTPG (Upbio Tech Co., Ltd., Shanghai, China) were qualified and quantified by HPLC as previously reported [13]. A ZORBAX SB- C18 Column $(250 \times 4.6 \mathrm{~mm} ; 5 \mu \mathrm{m})$ was used and the mobile phase was consisted of $0.2 \%$ formic acid solution and methanol with gradient from $23 \%$ to $31 \%$. A total of $10 \mu \mathrm{L}$ sample was injected and detected at $330 \mathrm{~nm}$. The echinacoside and acteoside standards (Yuanye, Shanghai, China) were used to analyze the components of CTPG.

\section{Analysis of cellular viability}

The antitumor effects of CTPG on HepG2 and BEL-7404 cells were assessed using MTT (3-(4, 5-dimethyl-2thiazolyl)-2, 5-diphenyl-2-H-tetrazolium bromide). HepG2 and BEL-7404 cells were plated into 96 -well plates $\left(5 \times 10^{4}\right.$ cells/well) and treated with 0, 200, 400 and $600 \mu \mathrm{g} / \mathrm{mL}$ CTPG for $24 \mathrm{~h}$ and $48 \mathrm{~h}$ respectively after $24 \mathrm{~h}$ of incubation at $37^{\circ} \mathrm{C} .35 \mu \mathrm{g} / \mathrm{mL}$ cisplatin (Yuanye) was used as positive control. $100 \mathrm{uL} \mathrm{MTT}(0.5 \mathrm{mg} / \mathrm{mL}$, diluted by medium without FBS medium) was added to each well and cultured for $3 \mathrm{~h}$ at $37^{\circ} \mathrm{C}$ and $5 \% \mathrm{CO}_{2}$. After incubation, 
the plates were centrifuged at $1200 \mathrm{rpm}$ for $7 \mathrm{~min}$, the medium was removed and $200 \mu \mathrm{g} / \mathrm{mL}$ DMSO was added to each well to dissolve the formed formazan crystals. The OD490 values were measured by a 96-well microplate reader (Bio-Rad Laboratories, CA, USA). To evaluate the effects of CTPG on splenocytes, the cells were isolated from C57BL/ 6 mice and plated into 96 -well plates at a density of $1 \times 10^{5}$ cells/well. Splenocytes were treated with 0 , 200,400 and $600 \mu \mathrm{g} / \mathrm{mL}$ for $24 \mathrm{~h}, 48 \mathrm{~h}$ and $72 \mathrm{~h}$, respectively. The cell viability was calculated as the followed formula: Cell viability $(\%)=\left(O D_{\text {treated }} / O D_{\text {untreated }}\right) \times 100 \%$.

\section{Detection of $\mathrm{Ki}-67$}

Detection of Ki-67 was done according to our previous study [16]. In briefly, BEL-7404 cells were treated with different concentrations $(0,200,400$ and $600 \mu \mathrm{g} / \mathrm{mL})$ of CTPG or cisplatin $(35 \mu \mathrm{g} / \mathrm{mL})$. After $24 \mathrm{~h}$, cells were harvested and washed with PBS, then fixed and permeabilized with Foxp3 Staining Buffer Set (eBioscience, USA) according to the manufacturer's instructions. Intracellular staining was performed using FITC conjugated $K i-67$ antibody (BD Biosciences, San Jose, CA, USA) for $15 \mathrm{~min}$ at RT. The samples were analyzed by flow cytometry (BD FACSCalibur, CA, USA).

\section{Analysis of cell apoptosis and cell cycle}

HepG2 and BEL-7404 cells were seeded at a density of $2.5 \times 10^{5}$ cells/dish and incubated at $37^{\circ} \mathrm{C}$ overnight. Cells were trypsinized and harvested by centrifugation after treatment with various concentrations of CTPG or pretreated with caspase inhibitor (Z-VAD-FMK) or caspase-3 inhibitor (Ac-DEVD-CHO) (Beyotime, China) for $2 \mathrm{~h}$ before CTPG treatment. After $24 \mathrm{~h}$, apoptosis was detected by flow cytometry. In brief, the collected cells were washed with cold

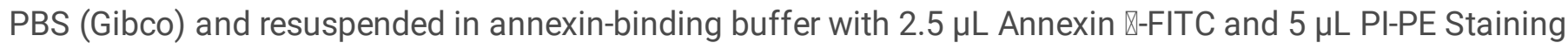
Solution (Solarbio, Beijing, China), and then cells were incubated at RT in the dark for 15 min. For analysis of the cell cycle distribution, cells were harvested after CTPG treatment and fixed in cold $70 \%$ ethanol at $4{ }^{\circ} \mathrm{C}$ for 30 min. Cells were stained with PI (BD Biosciences) in the dark for $30 \mathrm{~min}$. Samples were analyzed by flow cytometer (BD FACSCalibur). Expression levels of cell apoptosis and cycle-related proteins were detected by Western blot.

\section{Western blot}

Western blot was done according to our previous study [17]. HCC were treated with CTPG for $24 \mathrm{~h}$. After washing with ice-cold PBS twice, all adherent and floating cells were collected and lysed in RIPA Lysis Buffer (Beijing ComWin Biotech Co., Ltd) for 20 min on ice. After centrifugation at $12000 \mathrm{rpm} 4^{\circ} \mathrm{C}$ for $10 \mathrm{~min}$, protein concentration was determined using a Bicinchoninic Acid Assay Kit (Thermo Fisher Scientific, USA) according to the manufacturer's instructions. The same concentration of proteins were separated by $12 \%$ SDS-PAGE and transferred to PVDF membranes. After washing with PBST buffer (PBS with 0.05\% Tween-20), the membranes were blocked with $5 \%$ non-fat milk at $37^{\circ} \mathrm{C}$ for $1 \mathrm{~h}$, and then incubated with the primary antibodies (Cell Signaling Technology, MA, USA) at proper dilutions overnight at $4^{\circ} \mathrm{C}$. After washing three times with PBST, membrane was incubated with the corresponding HRP-conjugated secondary antibodies (eBioscience) for $2 \mathrm{~h}$ at $37^{\circ} \mathrm{C}$. The target proteins were detected using ECL assay kit (Beyotime).

\section{Analysis of mitochondrial membrane potential $(\Delta \Psi \mathrm{m})$}

$\Delta \psi \mathrm{m}$ was determined by membrane-permeable JC-1 dye (Beyotime). Briefly, HepG2 and BEL-7404 cells were treated with different concentrations of CTPG $(0,200,400$ and $600 \mu \mathrm{g} / \mathrm{mL})$ for $24 \mathrm{~h}$. All cells were collected and washed with in -1 waching huffar ralle warn ctainad with tho in -1 fluorescent probe according to manufacturer's Loading [MathJax]/jax/output/CommonHTML/fonts/TeX/fontdata.js 
instruction for 20 min at RT. After washing with PBS twice, all samples were analyzed by flow cytometry (BD FACSCalibur).

\section{Hoechst 33342 staining}

Hoechst 33342 staining was done according to our previous study [16]. The morphological changes of nuclei were examined using membrane-permeable DNA-binding dye Hoechst 33342 (Beyotime). Briefly, the cells were inoculated in 6-well plate at the concentration of $1 \times 10^{5}$ cells/well in $2 \mathrm{~mL}$ medium. When reaching $70 \%$ 80\% confluence, the cells were treated with 200,400 and $600 \mu \mathrm{g} / \mathrm{mL}$ of CTPG or cisplatin for $24 \mathrm{~h}$. The cells were washed with PBS and fixed with $4 \%$ ice-cold paraformaldehyde at $4^{\circ} \mathrm{C}$ for $10 \mathrm{~min}$. After washing with PBS, cells were stained with Hoechst 33342 at $4^{\circ} \mathrm{C}$ for $10 \mathrm{~min}$. Samples were observed by fluorescence inverted microscope (Nikon Eclipse Ti-E, Japan).

\section{Migration assay}

HCC cell migration was detected through wound healing assay. In brief, HepG2 cells ( $2 \times 10^{4} /$ well) were seeded in a 24-well plate. After reaching $80 \%$ confluence, the center of each well was scratched once with a $20 \mu \mathrm{L}$ pipette tip. After washing with PBS, cells were treated with cisplatin $(35 \mu \mathrm{g} / \mathrm{mL})$ or different concentrations $(0,200,400$ and $600 \mu \mathrm{g} / \mathrm{mL}$ ) of CTPG at $37^{\circ} \mathrm{C}$. After $24 \mathrm{~h}$, images of each sample were taken under a microscope (Nikon Eclipse Ti$\mathrm{E})$. The average distances of cell migration were analyzed by Image $\mathrm{J}$. The percentage of wound healing was calculated by the equation: wound healing $(\%)=(1$-scratch area at indicated time point/scratch area at $0 \mathrm{~h}) \times$ $100 \%$. Expression levels of cell migration-related proteins MMP-2 and VEGF were detected by Western blot.

\section{Proliferation and apoptosis of splenocytes}

For proliferation analysis, splenocytes were isolated from three C57BL/6 mice and stained with CFSE (eBioscience). CFSE labeled cells were inoculated into 24 -well plates at a density of $2 \times 10^{6}$ cells in $1 \mathrm{~mL}$ medium per well and treated with different concentrations of CTPG $(200,400$ and $600 \mu \mathrm{g} / \mathrm{mL})$ or combined with cisplatin for $72 \mathrm{~h}$. Flow cytometry analysis were performed after staining with CD3-APC and CD19-PE (BD Biosciences). For apoptosis analysis, splenocytes were inoculated into 24 -well plates at a density of $2 \times 10^{6}$ cells in $1 \mathrm{~mL}$ medium per well and treated with different concentrations of CTPG $(200,400$ and $600 \mu \mathrm{g} / \mathrm{mL})$ or combined with cisplatin for $24 \mathrm{~h}$. Flow cytometry analysis were performed after staining with $2.5 \mu \mathrm{L}$ Annexin $\mathrm{B}$-FITC and $5 \mu \mathrm{L}$ PI-PE Solution.

\section{Safety evaluation and immunostimulatory activities of CTPG in vivo}

For evaluating the in vivo immunostimulatory activities of CTPG, 6-8 weeks male Kunming mice were randomly divided into seven groups (5 mice/group). Subcutaneous injection (s.c., $200,400 \mathrm{mg} / \mathrm{kg}$ ), intraperitoneal injection (i.p., 200, $400 \mathrm{mg} / \mathrm{kg}$ ) and intragastric administration (i.g., 200, $400 \mathrm{mg} / \mathrm{kg}$ ) were applied every two days for a total of 7 times, while the control group did not receive any treatment. The mice were weighed every other day and the status of the mice was observed every day. After CTPG treatment, the organs of the mice were separated and weighed. The organ indexes were calculated according to the formula: organ index = organ weight (mg)/body weight (g). The splenocytes were collected, counted and stained with anti-CD3-APC, anti-CD19-PE, anti-CD49b-FITC or anti-CD4-APC, anti-CD44-PE, anti-CD8-FITC (BD Biosciences). Samples were detected by flow cytometry (BD FACSCalibur).

\section{Antitumor efficacy of CTPG combined with cisplatin in H22 tumor-bearing mice Loading [MathJax]/jax/output/CommonHTML/fonts/TeX/fontdata.js}


6-8 week-old male BALB/c mice were subcutaneously injected with $\mathrm{H} 22$ cells $\left(1.0 \times 10^{6}\right.$ per mouse in $100 \mu \mathrm{L}$ PBS). When the tumor volumes reached approximately $60 \mathrm{~mm}^{3}$, tumor mice were randomly divided into four groups (6 mice/group) and treated with cisplatin ( $4 \mathrm{mg} / \mathrm{kg})$, CTPG (400 mg/kg), cisplatin ( $\mathrm{mg} / \mathrm{kg})$ plus CTPG (400 mg/kg) or without treatment (control group), respectively. Tumor mice were intraperitoneally injected with CTPG on the $5^{\text {th }}$, $7^{\text {th }}, 9^{\text {th }}, 11^{\text {th }}$ and $13^{\text {th }}$ days, respectively. Cisplatin was intravenously injected on the $7^{\text {th }}$ and $11^{\text {th }}$ days. The tumor volume and body weight were measured every other day. Tumor volume was calculated as the following: Tumor volume $(V)=a \times b^{2} / 2$, in which $a$ and $b$ represented the longest and shortest diameter of a tumor measured by vernier caliper, respectively. On the $20^{\text {th }}$ day, organs and tumors were isolated and weighted. The splenocytes were collected, counted and stained with anti-CD3-APC and anti-CD19-PE or anti-CD4-FITC and anti-CD8-APC or antiCD11b-PE and anti-Gr-1-APC or anti-CD4-FITC, anti-CD25-APC and anti-Foxp3-PE (BD Biosciences). Subsequently, the frequencies and the numbers of the cells were analyzed by flow cytometry (BD FACSCalibur).

\section{Statistical analysis}

All data were expressed as mean \pm standard error of the mean (SEM). Statistical analysis was conducted using one-way analysis of variance (ANOVA) among the treatment and control groups using Prism5.0 software. $p<0.05$ was considered statistically significant.

\section{Results}

\section{CTPG inhibited the proliferation of HCC cells in vitro}

The components of CTPG were qualified and quantified by HPLC using echinacoside and acteoside standards (S Fig. 1A), which were the main components of phenylethanoid glycosides from Cistanche [18]. According to the peak retention times and the peak areas, CTPG contained $28 \%$ of echinacoside and $9.9 \%$ of acteoside. Besides, the content of polysaccharide in CTPG was $34.8 \%$ by phenol-sulfuric acid method [19]. To investigate whether CTPG can inhibit the growth of HCC, different concentrations of CTPG $(0,200,400,600 \mu \mathrm{g} / \mathrm{mL})$ were used to treat BEL7404 and HepG2 cells in vitro, and cisplatin was used as positive control. After treatment for $24 \mathrm{~h}$ and $48 \mathrm{~h}$, cell viability was detected by MTT assay. CTPG significantly reduced the viability of BEL-7404 and HepG2 cells in a dose- and time-dependent manner (Fig. 1A). Consistently, the proliferation of BEL-7404 cells was significantly inhibited by CTPG treatment, which was analyzed by Ki-67 staining (Fig. 1B). The effect of CTPG on the proliferation of splenocytes in vitro was also analyzed by MTT assay. We observed that CTPG enhanced the proliferation of splenocytes in a dose-dependent manner (Fig. 1C).

Mitogen-activated protein kinase (MAPK) signaling pathway plays pivotal role in the survival, differentiation and drug resistance of human cancer cells [20]. In order to investigate whether MAPK signaling pathway was involved in the inhibitory effect of CTPG on the proliferation of HCC cells, phosphorylation levels of various proteins from MAPK signal pathway were analyzed in HepG2 cells after treatment with CTPG at different concentrations and different time points. The phosphorylation of JNK (P-JNK) and p38 (P-p38) were dose-dependently enhanced by CTPG treatment. The phosphorylation of ERK (P-ERK) was down-regulated by 200 and $400 \mu \mathrm{g} / \mathrm{mL}$ CTPG treatment, while P-ERK was up-regulated under $600 \mu \mathrm{g} / \mathrm{mL}$ CTPG treatment (Fig. 1D). Moreover, the levels of P-JNK, P-p38 and P-ERK were up-regulated in a time-dependent way (Fig. 1D). These results suggested that CTPG might inhibit the proliferation of HCC cells through MAPK signaling pathway. 
We further analyzed whether CTPG inhibited HCC cell proliferation through induction of cell cycle arrest. After treatment with CTPG, an accumulation of BEL-7404 cells at S-phase was observed in a dose-dependent manner. Similarly, CTPG also induced HepG2 cell cycle arrest at S-phase and the frequencies increased from $40.66 \%$ in the control group to $61.90 \%$ in $600 \mu \mathrm{g} / \mathrm{mL}$ CTPG treated group (Fig. 2A). Cyclins and cyclin-dependent kinases (CDKs) play important roles in cell division control and development [21] which were associated with $\mathrm{G} / \mathrm{M}$ phase [22]. The expression level of Cyclin D1 was dose-dependently decreased by CTPG treatment, which promoted G1 to S phase progression. The expression levels of Cyclin B1, CDK1and CDK2 were also reduced, which were associated with G2/M phase (Fig. 2B). These results suggested that CTPG suppressed HCC cell proliferation by inducing cell cycle arrest.

\section{CTPG induced apoptosis of HCC cells}

Our previous studies showed that CTPG induced apoptosis in different tumor cells [13] (Fu et al.; Yuan et al). We also detected whether CTPG triggered apoptosis in HCC cells and found that CTPG induced apoptosis in HepG2 and BEL-7404 cells in a dose-dependent manner (Fig. 3A). The expression levels of anti-apoptotic B cell lymphoma 2 (Bcl-2) and pro-apoptotic BCL-2-associated X protein (Bax) were also analyzed by Western blot. The results showed that the expression levels of Bax and Bcl-2 were increased and decreased by CTPG treatment in a dosedependent manner, respectively (Fig. 3B). The apoptosis of HepG2 cells was further determined by Hoechst 33342 staining after treatment with CTPG for $24 \mathrm{~h}$. The nuclear morphology was observed by inverted fluorescence microscope. As shown in Fig. 3C, the control HepG2 cells were homogeneously stained while HepG2 cells treated with CTPG showed chromatin condensation and fragmentation in a dose-dependent manner, which were similar with HepG2 cells treated with cisplatin. These results indicated that CTPG induced apoptosis of HCC cells.

\section{CTPG activated mitochondria-dependent apoptosis pathway in HCC cells}

The integrity of the outer mitochondrial membrane is strictly regulated by Bcl-2 family and the reduction of $\Delta \Psi_{\mathrm{m}}$ promotes the release of cytochrome $c$ that activates caspase cascade to induce apoptosis [23] [24]. When $\Delta \psi_{\mathrm{m}}$ decreases, the JC-1 polymer (red fluorescence) decomposes into monomers (green fluorescence) [25]. The above result showed the up-regulation of Bax and down-regulation of Bcl-2. Therefore, the $\Delta \psi_{\mathrm{m}}$ of $\mathrm{HCC}$ cells were detected by JC-1 staining after CTPG treatment for $24 \mathrm{~h}$. As shown Fig. 4A, the green fluorescence intensity of the FL-1 channel was dose-dependently increased by CTPG treatment while the red fluorescence intensity of the FL-2 channel was dose-dependently decreased in both BEL-7404 and HepG2 cells. Inverted fluorescence microscope observation exhibited similar result (Fig. 4B), indicating that CTPG reduces the $\Delta \psi_{\mathrm{m}}$ of HCC cells. Subsequently, we observed the levels of cytochrome $c$ were increased in both BEL-7404 and HepG2 cells after CTPG treatment (Fig. 4C), which further confirmed the reduction of $\Delta \Psi_{m}$ in CTPG treated HCC cells.

The release of cytochrome $c$ can activate the initiator caspase-9 to induce apoptosis (ref). After CTPG treatment for $24 \mathrm{~h}$, the protein levels of caspase-3, caspase-9, caspase-7, caspase-8 as well as the levels of their corresponding cleaved proteins were detected in BEL-7404 and HepG2 cells by Western blot. The levels of cleaved-caspase-3, cleaved-caspase-7, cleaved-caspase-9 were increased while the levels of cleaved-caspase-8 was not changed (Fig.5A). The activated caspase-3 can cleave the DNA repair enzyme of poly (ADP-ribose) polymerase (PARP) to prevent DNA repair and accumulate DNA damage (ref). We also observed the up-regulated levels of cleaved-PARP.

The role of caspase cascade in HCC cell apoptosis induced by CTPG was further determined by using caspase inhibitor (Z-VAD-FMK) and casnase-3 inhibitor (Ac-DEVD-CHO) respectively. Z-VAD-FMK significantly reversed the Loading [MathJax]/jax/output/CommonHTML/fonts/TeX/fontdata.js 
apoptosis of BEL-7404 and HepG2 cells induced by CTPG (Fig. 5B). Similarly, Ac-DEVD-CHO also significantly reversed the apoptosis of HepG2 cells induced by CTPG (Fig. 5C). The results demonstrated that CTPG induced apoptosis of HCC cells by mitochondria-dependent pathway.

\section{CTPG suppressed HCC cell migration in vitro}

Cancer cell migration is considered one of the critical processes in tumor metastasis. To determine whether CTPG affect HCC cell migration, HepG2 cell motility was evaluated by wound-healing assay. As shown in Fig. 6A \& B, HepG2 cell migration was significantly inhibited by CTPG treatment in a dose-dependent manner. MMP family and VEGF play critical roles in the migration of tumor cells [26]. After CTPG treatment for $24 \mathrm{~h}$, the levels of MMP-2 and VEGF were significantly decreased (Fig. $6 \mathrm{C}$ ), suggesting that CTPG might suppress the invasion and metastasis of HCC.

\section{CTPG enhanced the immunity of mice}

It has been reported that Cistanche deserticola polysaccharides have immunomodulatory functions including promoting lymphocyte proliferation and activating macrophages [27]. CTPG contained $34.8 \%$ polysaccharide content. Therefore, we examined the effects of CTPG on the proliferation of T cells and B cells. As shown in S Fig. 2A, CTPG significantly increased the proliferation of T cells and B cells in a dose-dependent manner, even in the presence of cisplatin. Interestingly, CTPG significantly inhibited the apoptosis of splenocytes induced by cisplatin (S Fig. 2B), indicating that CTPG could ameliorate the side effect of cisplatin on the immune system of mice.

We further evaluated the immunostimulatory effect of CTPG on mice. After i.p. injection, s.c. injection and i.g. administration of CTPG (200 and $400 \mathrm{mg} / \mathrm{Kg}$ ), there was no significant change in the state of mice compared with the untreated group. The body weight of mice also had no significant difference among CTPG-treated groups and untreated group (Fig. 7A). The heart, liver, spleen, lung, kidney and thymus indexes of mice were similar among all groups except the spleen indexes of mice in $400 \mathrm{mg} / \mathrm{Kg}$ CTPG i.p. injection group (Table 1). The results showed that the selected doses of CTPG had no side effect in mice.

As i.p. injection of CTPG significantly increased the spleen index, we further analyzed the numbers of various immune cells in spleen. The results showed that i.p. injection of CTPG significantly increased the numbers of T cells (CD3 ${ }^{+} \mathrm{CD} 19^{-}$cells), B cells (CD3-CD19+ cells) and NK cells (CD3-CD19-CD 49b ${ }^{+}$cells) compared with the untreated group. Moreover, i.p. injection of CTPG not only significantly increased the numbers of $\mathrm{CD} 4^{+}$and $\mathrm{CD} 8^{+} \mathrm{T}$ cells but also enhanced the activation state of $\mathrm{CD} 4^{+} \mathrm{T}$ cells $\left(\mathrm{CD} 4^{+} \mathrm{CD} 44^{+}\right.$cells) (Fig. 7B), suggesting that CTPG had immune enhancement function.

\section{The combination of CTPG and cisplatin exhibited potent antitumor effect on $\mathrm{H} 22$ tumor mouse model}

The above result showed that CTPG could ameliorate the side effect of cisplatin on immune system. Therefore, the antitumor effect of CTPG combined with cisplatin was evaluated on H22 tumor mouse model. As shown in Fig. 8A, CTPG alone, cisplatin alone and the combination of CTPG and cisplatin (CTPG+cisplatin) significantly suppressed $\mathrm{H} 22$ tumor growth compared with control group. CTPG+cisplatin showed stronger inhibitory effect than that of CTPG and cisplatin alone. On the $20^{\text {th }}$ day, the tumor volumes in the control, cisplatin alone, CTPG alone and CTPG+cisplatin groups were about $1707.8 \mathrm{~mm}^{3}, 722.5 \mathrm{~mm}^{3}, 1033.8 \mathrm{~mm}^{3}$ and $367.5 \mathrm{~mm}^{3}$, respectively. On the same day, the tumors were collected for visual observation (Fig. 8B) and weight comparison (Fig. 8C).

Loading [MathJax]/jax/output/CommonHTML/fonts/TeX/fontdata.js 
CTPG+cisplatin showed better therapeutic effects on H22 tumor mouse model than CTPG or cisplatin alone. The tumor weight in CTPG+cisplatin group was lower than that in other groups.

The body weights of mice were measured to reflect the health status of mice. The body weight remarkably decreased after cisplatin treatment, suggesting that cisplatin induced severe systemic toxicity [28]. In comparison, CTPG combined with cisplatin significantly ameliorated body weight loss induced by cisplatin, while CTPG alone had no significant effect on mice body weight (Fig. 8D). The organs including spleen, heart, liver, lung, kidney and thymus were also isolated to calculate organ indexes. Compared with untreated group, spleen indexes were significantly decreased and increased by cisplatin and CTPG, respectively. CTPG+cisplatin recovered spleen indexes compared with cisplatin alone. Other organ indexes had no significant difference among all groups (Table 2).

\section{CTPG combined with cisplatin enhanced the immunity of tumor mice}

The above results showed that CTPG enhanced the immunity of mice and inhibited the apoptosis of splenocytes induced by cisplatin. We further investigated whether the antitumor effect of CTPG+cisplatin was correlated with enhanced immunity. The spleens of tumor-bearing mice were collected to detect the numbers of $T$ cells, $B$ cells, myeloid-derived suppressor cells (MDSCs) and regulatory T cells (Tregs) by flow cytometry. The frequencies and numbers of $\mathrm{T}$ cells including $\mathrm{CD} 4^{+}$and $\mathrm{CD} 8^{+} \mathrm{T}$ cells in CTPG+cisplatin group were significantly higher than those in control and cisplatin groups (Fig. 9A\&B). Compared with control group, CTPG alone also partly increased the numbers of $\mathrm{CD}^{+}$and $\mathrm{CD} 8^{+} \mathrm{T}$ cells although there was no significant difference. The frequencies and numbers of $\mathrm{B}$ cells had no significant difference among all groups.

MDSCs and Tregs expended in tumors and inhibited antitumor immune responses [29, 30]. The frequencies and numbers of MDSCs $\left(\mathrm{CD} 11 \mathrm{~b}^{+} \mathrm{Gr}-1^{+}\right)$, macrophages $\left(\mathrm{CD} 11 \mathrm{~b}^{+} \mathrm{Gr}-1^{-}\right)$and Tregs (natural Tregs: $\mathrm{CD} 4^{+} \mathrm{CD} 25^{+}$Foxp3 ${ }^{+}$; induced Tregs: $\mathrm{CD} 4^{+} \mathrm{CD} 25^{-}$Foxp $3^{+}$) in the spleens of tumor mice were analyzed by flow cytometry. Compared with control group, the frequencies and numbers of MDSCs decreased significantly after injection with cisplatin alone or

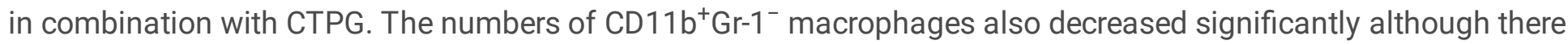
was no significant change in their frequencies (Fig. 9C). In addition, CTPG alone and CTPG+cisplatin treatment significantly decreased the frequencies of induced Tregs (Fig. 9D). These results suggested that the antitumor effect of CTPG+cisplatin might be corrected with the enhanced immunity characterized by the increased numbers of $T$ cells and the decreased numbers of MDSCs and Tregs.

\section{Discussion}

It has been reported that traditional CHM could induce apoptosis of various tumor cells through different pathways, including the extrinsic death receptor, intrinsic mitochondrial and endoplasmic reticulum (ER) stress pathways [31]. Our previous study showed that N-butanol subfraction of Brassica rapa L. induced apoptosis of A549 lung adenocarcinoma cells [16] and ethanol extracts of cultivated and wild Pleurotus ferulae induced apoptosis of $\mathrm{H} 22$ cells via ER stress- and mitochondria-dependent pathway [17]. We also reported that CTPG inhibited the growth of melanoma B16-F10 cells and esophageal carcinoma Eca-109 cells through the induction of apoptosis via a mitochondrial-dependent pathway [13]. In the present study, we found that CTPG inhibited the growth of human HCC HepG2 and BEL-7404 cells through activation of the MAPK signal pathway and induction of apoptosis via mitochondria-dependent pathway. Bax and Bcl-2 play a critical role in mitochondria-dependent apoptosis pathway Loading [MathJax]/jax/output/CommonHTML/fonts/TeX/fontdata.js ff Bax and reduced the expression of Bcl-2 in HepG2 and 
BEL-7404 cells, which resulted in the reduction of $\Delta \psi m$ and the release of cytochrome $c$ to activate caspase cascade. The up-regulated levels of cleaved-caspase- 9 and cleaved-caspase- 3 were observed after CTPG treatment, while the levels of cleaved-caspase-8 were not changed by CTPG treatment, suggesting that the apoptosis of HepG2 and BEL-7404 cells induced by CTPG was not mediated by extrinsic signaling pathway. However, our previous study showed that CTPG induced the apoptosis of H22 cells through both intrinsic and extrinsic pathways [15]. These results suggested that CTPG might inhibit the growth of tumor cells through multiple targets and pathways.

TCM has been widely used for treating cancer through multiple signal pathways with or without minor side effects [32]. MAPK signaling pathway is closely related to the occurrence, invasion and metastasis of tumor cells, which mainly involved in p38 pathway, JNK/SAPK pathway and ERK1/2 pathway [20]. The activation of p38 and JNK can induce apoptosis but the activation of ERK1/2 can be an anti-apoptotic or pro-apoptotic agent depending on the cell properties [33]. It has been reported that CHM induced the apoptosis of tumor cells by activating p38, JNK or ERK MAPK pathways [34, 35]. We found that CTPG up-regulated the phosphorylated levels of p38, JNK and ERK, suggesting that MAPK signaling pathway might be involved in the apoptosis of HCC cells induced by CTPG.

Chemotherapy and radiotherapy can cause various adverse events including the suppression of the immune system. In order to improve the clinical efficacy of chemotherapy, natural polysaccharides have been approved to be used as adjuvants for cancer treatment. It has been reported that the combination of lentinan and chemotherapeutic agent tegafur improved the clinical efficacy of patients with esophageal carcinoma through enhancing the patient's immune function [36]. In our previous studies, the in vivo inhibitory effect of CTPG on tumor growth is related to not only its direct antitumor effect but also its immune enhancement function $[13,15]$. The immune enhancement function of CTPG might be correlated with its polysaccharide content. Here, the in vivo antitumor effect of CTPG+cisplatin was investigated. In H22 tumor mouse model, CTPG+cisplatin not only showed best antitumor effect but also reduced the side effects of cisplatin. CTPG+cisplatin enhanced the immunity of tumor mice through increasing the numbers of $\mathrm{CD} 4^{+}$and $\mathrm{CD} 8^{+} \mathrm{T}$ cells and decreasing the numbers of MDSCs and Tregs, which participated in tumor-induced inhibitory microenvironment, promoted tumor growth and inhibited immune response [37]. The increased numbers of T cells might be corrected with their proliferation promoted by CTPG and their decreased apoptosis protected by CTPG. However, the mechanisms of CTPG to reduce the numbers of MDSCs and Tregs need further investigation.

\section{Conclusions}

CTPG induced apoptosis in HCC cells through both mitochondria-dependent and MAPK signaling pathways in vitro and inhibited the growth of HCC through direct antitumor effect and indirect immune enhancement in combination with cisplatin. CTPG might serve as a potential candidate for the treatment of HCC.

\section{Abbreviations}

JNK/SAPK/ERK: stress-activated protein kinases/c-Jun N-terminal kinase/extracellular regulated protein kinases;

P-JNK/P-p38/P-ERK: the phosphorylation of c-Jun N-terminal kinase/the phosphorylation of p38/the phosphorylation of extracellular regulated protein kinases;

BEL-7404 and HepG2: human hepatocellular liver carcinoma cell line;

Loading [MathJax]/jax/output/CommonHTML/fonts/TeX/fontdata.js

Page $11 / 25$ 
H22: mouse hepatocellular liver carcinoma cell line;

JC-1: mitochondrial membrane-potential eye;

PBS: phosphate buffered saline;

PVDF: polyvinylidene fluoride;

Hoechst 33342: DNA blue fluorescent dye;

Other abbreviations have been provided in the article.

\section{Declarations}

\section{Ethics approval and consent to participate}

The experimental protocol was approved by the Committee on the Ethics of Animal Experiments of Xinjiang Key Laboratory of Biological Resources and Genetic Engineering (BRGE-AE001).

\section{Consent for publication}

Not applicable.

\section{Availability of data and materials}

The data used to support the findings of this study are available from the corresponding author upon request.

\section{Conflict of interest}

The authors declare no competing interests.

\section{Funding}

This work was supported by the National Natural Science Foundation of China (U1803381 to Jinyao Li and 31860258 to Lijie Xia), and the Doctoral Start-up Foundation of Xinjiang University (BS180222).

\section{Authors' contributions}

P.Y., C.F., Y.Y., A.A., F.Z. and X.W. performed experiments. W.W., J.L. and Y.L. analyzed data and prepared figures. L.X. and J.L. designed the experiments and wrote the manuscript. All authors reviewed the manuscript.

\section{Acknowledgment}

Not applicable.

\section{References}

1. Bray F, Ferlay J, Soerjomataram I, Siegel RL, Torre LA, Jemal A. Global cancer statistics 2018: GLOBOCAN estimates of incidence and mortality worldwide for 36 cancers in 185 countries. CA Cancer J Clin. 
2. Chen W, Zheng R, Baade PD, Zhang S, Zeng H, Bray F, et al. Cancer statistics in China, 2015. CA Cancer J Clin. 2016;66(2):115-32.

3. Forner A, Reig ME, de Lope CR, Bruix J. Current strategy for staging and treatment: the BCLC update and future prospects. Semin Liver Dis. 2010;30(1):61-74.

4. EASL-EORTC clinical practice guidelines: management of hepatocellular carcinoma. J Hepatol. 2012;56(4):908-43.

5. Omata M, Lesmana LA, Tateishi R, Chen PJ, Lin SM, Yoshida H, et al. Asian Pacific Association for the Study of the Liver consensus recommendations on hepatocellular carcinoma. Hepatol Int. 2010;4(2):439-74.

6. Zhu YJ, Zheng B, Wang HY, Chen L. New knowledge of the mechanisms of sorafenib resistance in liver cancer. Acta Pharmacol Sin. 2017;38(5):614-22.

7. Yang Z, Liao X, Lu Y, Xu Q, Tang B, Chen X, et al. Add-On Therapy with Traditional Chinese Medicine Improves Outcomes and Reduces Adverse Events in Hepatocellular Carcinoma: A Meta-Analysis of Randomized Controlled Trials. Evid Based Complement Alternat Med. 2017;2017:3428253.

8. Shi Z, Song T, Wan Y, Xie J, Yan Y, Shi K, et al. A systematic review and meta-analysis of traditional insect Chinese medicines combined chemotherapy for non-surgical hepatocellular carcinoma therapy. Sci Rep. 2017;7(1):4355.

9. Wu CR, Lin HC, Su MH. Reversal by aqueous extracts of Cistanche tubulosa from behavioral deficits in Alzheimer's disease-like rat model: relevance for amyloid deposition and central neurotransmitter function. BMC Complement Altern Med. 2014;14:202.

10. Nan ZD, Zeng KW, Shi SP, Zhao MB, Jiang Y, Tu PF. Phenylethanoid glycosides with anti-inflammatory activities from the stems of Cistanche deserticola cultured in Tarim desert. Fitoterapia. 2013;89:167-74.

11. Jiang Y, Tu PF. Analysis of chemical constituents in Cistanche species. J Chromatogr A. 2009;1216(11):1970-9.

12. Morikawa T, Pan Y, Ninomiya K, Imura K, Matsuda H, Yoshikawa M, et al. Acylated phenylethanoid oligoglycosides with hepatoprotective activity from the desert plant Cistanche tubulosa. Bioorg Med Chem. 2010;18(5):1882-90.

13. Li J, Li J, Aipire A, Gao L, Huo S, Luo J, et al. Phenylethanoid Glycosides from Cistanche tubulosa Inhibits the Growth of B16-F10 Cells both in Vitro and in Vivo by Induction of Apoptosis via Mitochondria-dependent Pathway. J Cancer. 2016;7(13):1877-87.

14. Fu C, Li J, Aipire A, Xia L, Yang Y, Chen Q, et al. Cistanche tubulosa phenylethanoid glycosides induce apoptosis in Eca-109 cells via the mitochondria-dependent pathway. Oncol Lett. 2019;17(1):303-13.

15. Yuan P, Li J, Aipire A, Yang Y, Xia L, Wang X, et al. Cistanche tubulosa phenylethanoid glycosides induce apoptosis in $\mathrm{H} 22$ hepatocellular carcinoma cells through both extrinsic and intrinsic signaling pathways. BMC Complement Altern Med. 2018;18(1):275.

16. Aipire A, Chen Q, Cai S, Li J, Fu C, Ying T, et al. N-Butanol Subfraction of Brassica Rapa L. Promotes Reactive Oxygen Species Production and Induces Apoptosis of A549 Lung Adenocarcinoma Cells via MitochondriaDependent Pathway. Molecules. 2018;23(7).

17. Yang Y, Yuan P, Wei X, Fu C, Li J, Wang W, et al. Cultivated and wild Pleurotus ferulae ethanol extracts inhibit hepatocellular carcinoma cell growth via inducing endoplasmic reticulum stress- and mitochondria-dependent apoptosis. Scientific Reports. 2018;8(1).

18. Jiang Y, Li SP, Wang YT, Chen XJ, Tu PF. Differentiation of Herba Cistanches by fingerprint with high- 
2009;1216(11):2156-62.

19. Masuko T, Minami A, Iwasaki N, Majima T, Nishimura S, Lee YC. Carbohydrate analysis by a phenol-sulfuric acid method in microplate format. Anal Biochem. 2005;339(1):69-72.

20. De Luca A, Maiello MR, D'Alessio A, Pergameno M, Normanno N. The RAS/RAF/MEK/ERK and the PI3K/AKT signalling pathways: role in cancer pathogenesis and implications for therapeutic approaches. Expert Opin Ther Targets. 2012;16 Suppl 2:S17-27.

21. Lee Y, Lahens NF, Zhang S, Bedont J, Field JM, Sehgal A. G1/S cell cycle regulators mediate effects of circadian dysregulation on tumor growth and provide targets for timed anticancer treatment. PLoS biology. 2019;17(4):e3000228.

22. Gao SY, Li J, Qu XY, Zhu N, Ji YB. Downregulation of Cdk1 and cyclinB1 expression contributes to oridonininduced cell cycle arrest at G2/M phase and growth inhibition in SGC-7901 gastric cancer cells. Asian Pacific journal of cancer prevention : APJCP. 2014;15(15):6437-41.

23. Zamzami N, Marchetti P, Castedo M, Zanin C, Vayssière JL, Petit PX, et al. Reduction in mitochondrial potential constitutes an early irreversible step of programmed lymphocyte death in vivo. J Exp Med. 1995;181(5):166172.

24. Martinou JC, Youle RJ. Mitochondria in apoptosis: Bcl-2 family members and mitochondrial dynamics. Dev Cell. 2011;21(1):92-101.

25. Z. Z. Chong S-HL, F. Li, K. Maiese \%J Current Neurovascular Research. The Sirtuin Inhibitor Nicotinamide Enhances Neuronal Cell Survival During Acute Anoxic Injury Through AKT, BAD, PARP, and Mitochondrial Associated "Anti-Apoptotic" Pathways. 2005;2(4):p.271-85.

26. Liu QH, Wang Y, Yong HM, Hou PF, Pan J, Bai J, et al. XRCC1 serves as a potential prognostic indicator for clear cell renal cell carcinoma and inhibits its invasion and metastasis through suppressing MMP-2 and MMP-9. Oncotarget. 2017;8(65):109382-92.

27. Dong Q, Yao J, Fang JN, Ding K. Structural characterization and immunological activity of two cold-water extractable polysaccharides from Cistanche deserticola Y. C. Ma. Carbohydr Res. 2007;342(10):1343-9.

28. Zhu J, Xu J, Jiang LL, Huang JQ, Yan JY, Chen YW, et al. Improved antitumor activity of cisplatin combined with Ganoderma lucidum polysaccharides in U14 cervical carcinoma-bearing mice. Kaohsiung J Med Sci. 2019;35(4):222-9.

29. Gabrilovich DI, Nagaraj S. Myeloid-derived suppressor cells as regulators of the immune system. Nat Rev Immunol. 2009;9(3):162-74.

30. Kryczek I, Liu R, Wang G, Wu K, Shu X, Szeliga W, et al. FOXP3 defines regulatory T cells in human tumor and autoimmune disease. Cancer Res. 2009;69(9):3995-4000.

31. Peng KZ, Ke Y, Zhao Q, Tian F, Liu HM, Hou G, et al. OP16, a novel ent-kaurene diterpenoid, potentiates the antitumor effect of rapamycin by inhibiting rapamycin-induced feedback activation of Akt signaling in esophageal squamous cell carcinoma. Biochem Pharmacol. 2017;140:16-27.

32. Yan Z, Lai Z, Lin J. Anticancer Properties of Traditional Chinese Medicine. Comb Chem High Throughput Screen. 2017;20(5):423-9.

33. Yang Y, Zhu X, Chen Y, Wang X, Chen R. p38 and JNK MAPK, but not ERK1/2 MAPK, play important role in colchicine-induced cortical neurons apoptosis. Eur J Pharmacol. 2007;576(1-3):26-33.

34. Chou SM, Lai WJ, Hong T, Tsai SH, Chen YH, Kao CH, et al. Involvement of p38 MAPK in the Anticancer Activity 
35. Wong DJ, Robert L, Atefi MS, Lassen A, Avarappatt G, Cerniglia M, et al. Erratum to: Antitumor activity of the ERK inhibitor SCH722984 against BRAF mutant, NRAS mutant and wild-type melanoma. Mol Cancer. $2015 ; 14: 128$.

36. Wang JL, Bi Z, Zou JW, Gu XM. Combination therapy with lentinan improves outcomes in patients with esophageal carcinoma. Mol Med Rep. 2012;5(3):745-8.

37. Kobayashi A, Weinberg V, Darragh T, Smith-McCune K. Evolving immunosuppressive microenvironment during human cervical carcinogenesis. Mucosal Immunol. 2008;1(5):412-20.

\section{Tables}

Table 1. Organ indexes of mice

\begin{tabular}{|c|c|c|c|c|c|c|c|}
\hline \multirow[b]{2}{*}{ Indexes } & \multirow[b]{2}{*}{ Untreated } & \multicolumn{2}{|l|}{ i.p. $(\mathrm{mg} / \mathrm{Kg})$} & \multicolumn{2}{|l|}{ s.c. $(\mathrm{mg} / \mathrm{Kg})$} & \multicolumn{2}{|l|}{ i.g. $(\mathrm{mg} / \mathrm{Kg})$} \\
\hline & & 200 & $\star \star \star$ & 200 & 400 & 200 & 400 \\
\hline & & & 400 & & & & \\
\hline Spleen & $3.44 \pm 0.82$ & $3.98 \pm 0.5$ & $5.33 \pm 1.18$ & $3.3 \pm 0.4$ & $4.28 \pm 0.52$ & $3.45 \pm 0.57$ & $3.73 \pm 0.32$ \\
\hline Heart & $5.48 \pm 0.61$ & $5.03 \pm 0.73$ & $5.42 \pm 0.48$ & $5.25 \pm 0.75$ & $6.16 \pm 0.43$ & $5.16 \pm 0.52$ & $4.29 \pm 0.35$ \\
\hline Liver & $77.18 \pm 3.81$ & $74.86 \pm 5.95$ & $78.94 \pm 3.95$ & $70.09 \pm 7.99$ & $77.65 \pm 4.96$ & $72.69 \pm 6.2$ & $72.58 \pm 7.37$ \\
\hline Lung & $9.1 \pm 1.85$ & $7.8 \pm 0.56$ & $8.77 \pm 1.05$ & $9.56 \pm 1.1$ & $8.47 \pm 1.56$ & $7.47 \pm 0.77$ & $8.5 \pm 0.51$ \\
\hline Kidney & $16.06 \pm 2.98$ & $13.66 \pm 1.05$ & $16.27 \pm 1.96$ & $16.42 \pm 2.32$ & $16.28 \pm 1.25$ & $15.13 \pm 1.38$ & $16.83 \pm 0.97$ \\
\hline Thymus & $6.00 \pm 0.74$ & $5.65 \pm 1.52$ & $5.29 \pm 0.6$ & $4.68 \pm 1.01$ & $4.5 \pm 0.83$ & $5.3 \pm 0.86$ & $4.91 \pm 0.47$ \\
\hline
\end{tabular}

$\star \star \star ~ p<0.001$ compared with untreated group.

Table 2. Organ indexes of H22 tumor-bearing mice

\begin{tabular}{|c|c|c|c|c|}
\hline Indexes & Untreated & $\star \star \star$ & * & \# \\
\hline & & Cisplatin & CTPG & CTPG+Cisplatin \\
\hline Spleen & $9.99 \pm 0.68$ & $7.62 \pm 0.68$ & $11.63 \pm 0.80$ & $8.71 \pm 0.90$ \\
\hline Heart & $5.67 \pm 0.37$ & $6.22 \pm 0.59$ & $5.84 \pm 0.36$ & $5.32 \pm 0.18$ \\
\hline Liver & $65.38 \pm 4.14$ & $72.99 \pm 10.37$ & $61.67 \pm 1.58$ & $62.29 \pm 6.64$ \\
\hline Lung & $6.39 \pm 0.58$ & $7.9 \pm 1.10$ & $7.37 \pm 1.54$ & $6.07 \pm 0.57$ \\
\hline Kidney & $17.59 \pm 0.77$ & $18.62 \pm 3.28$ & $17.41 \pm 0.84$ & $16.12 \pm 1.51$ \\
\hline The & $11 n+n \cap a$ & $1 \cap 1+\cap 17$ & $1.14 \pm 0.19$ & $0.89 \pm 0.11$ \\
\hline
\end{tabular}


${ }^{*} p<0.05 ;{ }^{* *} p<0.001$ compared with untreated group; \# $p<0.05$ compared with cisplatin group.

\section{Figures}

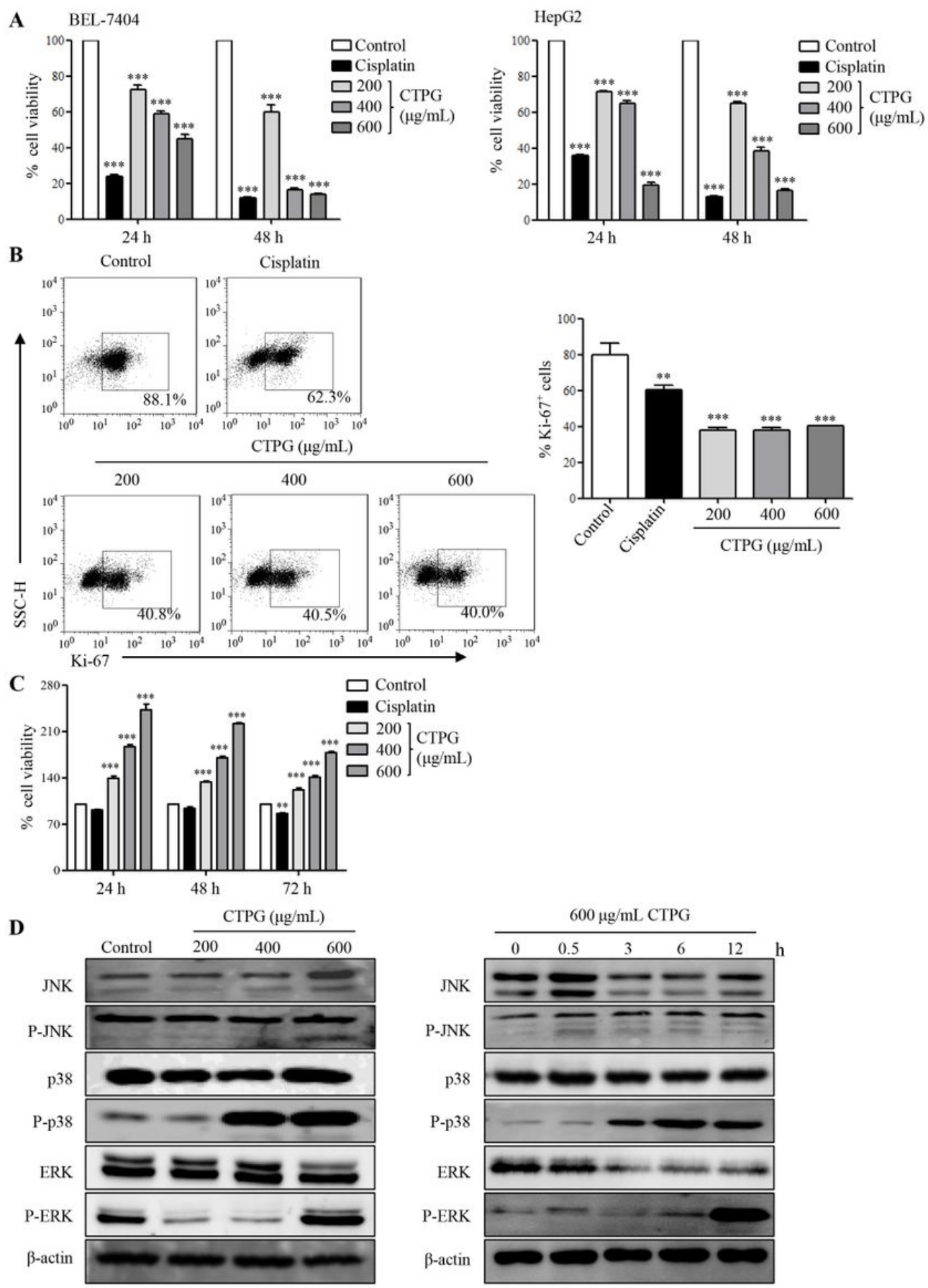

\section{Figure 1}

The effect of CTPG on the proliferation of HCC cells and splenocytes. (A) BEL-7404 and HepG2 cells were treated by different concentrations $(0,200,400,600 \mu \mathrm{g} / \mathrm{mL})$ of CTPG for 24 and $48 \mathrm{~h}$, and then cell viability was detected by MTT assay. (B) BEL-7404 cells were treated with different concentrations of CTPG for $24 \mathrm{~h}$, and the frequencies of Ki-67+ cells were detected by flow cytometry. (C) Splenocytes of C57BL/ 6 mice were treated with different 
concentrations of CTPG for 24, 48 and $72 \mathrm{~h}$, and the proliferation was analyzed by MTT assay. ** $p<0.01, * \star \star p<$ 0.001, compared with control. (D) HepG2 cells were treated with different concentration of CTPG for $24 \mathrm{~h}$ or treated with $600 \mu \mathrm{g} / \mathrm{mL}$ CTPG for $0,0.5,3,6$ and $12 \mathrm{~h}$, then proteins were isolated to detect MAPK signaling pathway proteins by Western blot.

A
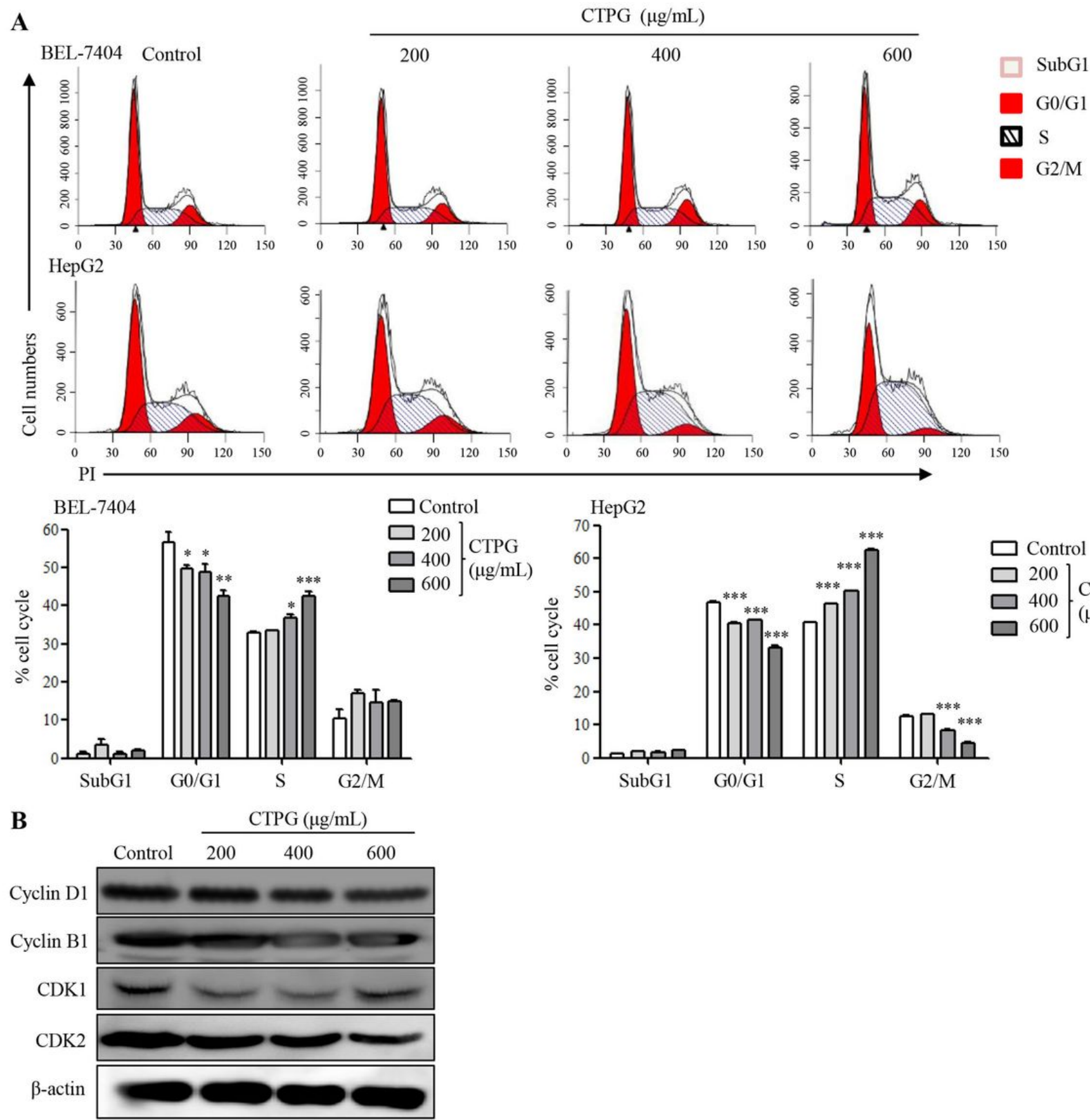

Figure 2

The effects of CTPG on cell cycle in HCC cells. (A) BEL-7404 and HepG2 cells were treated with different concentrations $(0,200,400,600 \mu \mathrm{g} / \mathrm{mL})$ of CTPG for $24 \mathrm{~h}$. Cell cycle distribution in HCC cells was analyzed by flow cytometry. ${ }^{*} p<0.05 ;{ }^{* *} p<0.01$; ${ }^{* *} p<0.001$ compared with control. (B) HepG2 cells were treated with different concentration of CTPG for $24 \mathrm{~h}$, and proteins were isolated to detect the levels of cyclinD1, CDK2, cyclinB1 and 
A
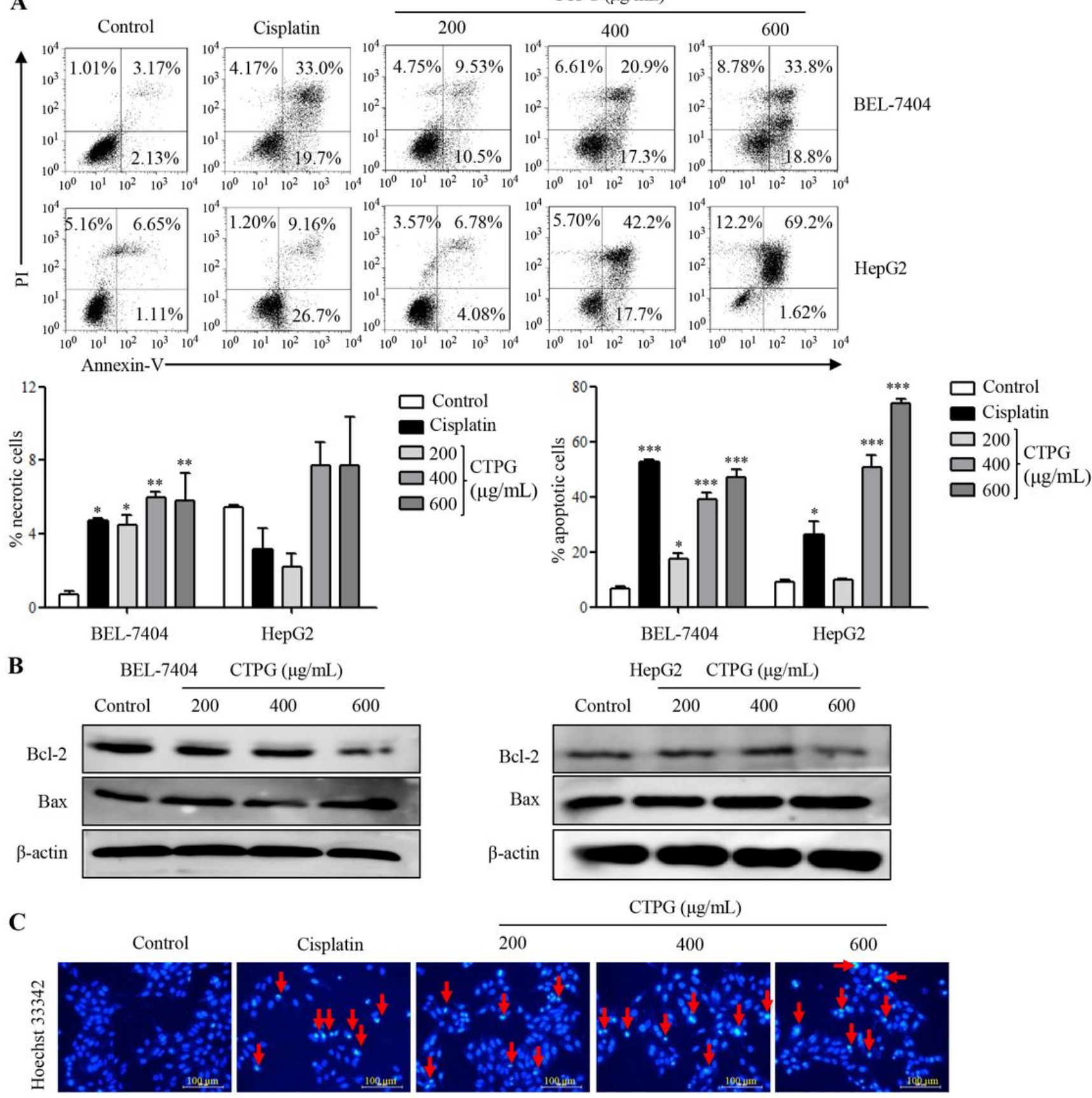

C

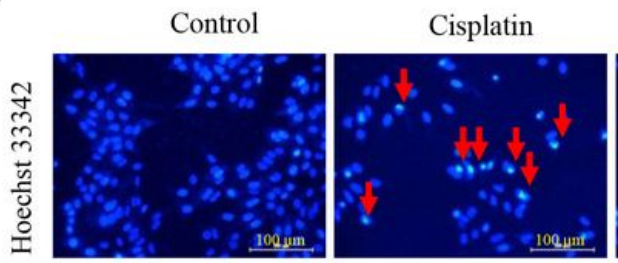

Figure 3

The effects of CTPG on apoptosis in HCC cells. Cells were treated with different concentrations $(0,200,400,600$ $\mu \mathrm{g} / \mathrm{mL}$ ) of CTPG for $24 \mathrm{~h}$. (A) The necrotic and apoptotic BEL-7404 and HepG2 cells were detected by flow cytometry. The upper panel showed the individual dot plots and the lower panel showed the summary data. * $p<$ $0.05 ;{ }^{* \star} p<0.01 ; * \star * p<0.001$ compared with control. (B) Total protein was isolated to analyze the expressions of Bax and Bcl-2 by Western blot. (C) HepG2 cells were stained with Hoechst 33342 and observed by inverted fluorescence microscopy. The arrows indicated the chromosomal condensation or fragmentation. 
A
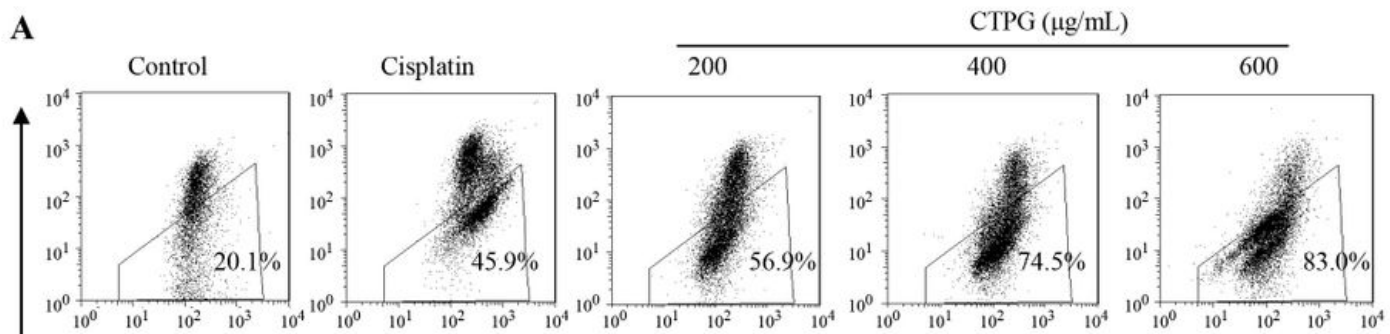

BEL-7404
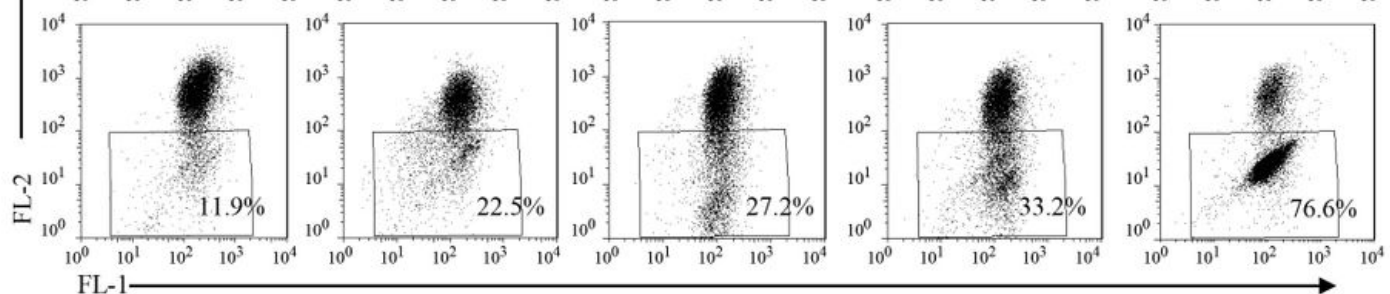

HepG2
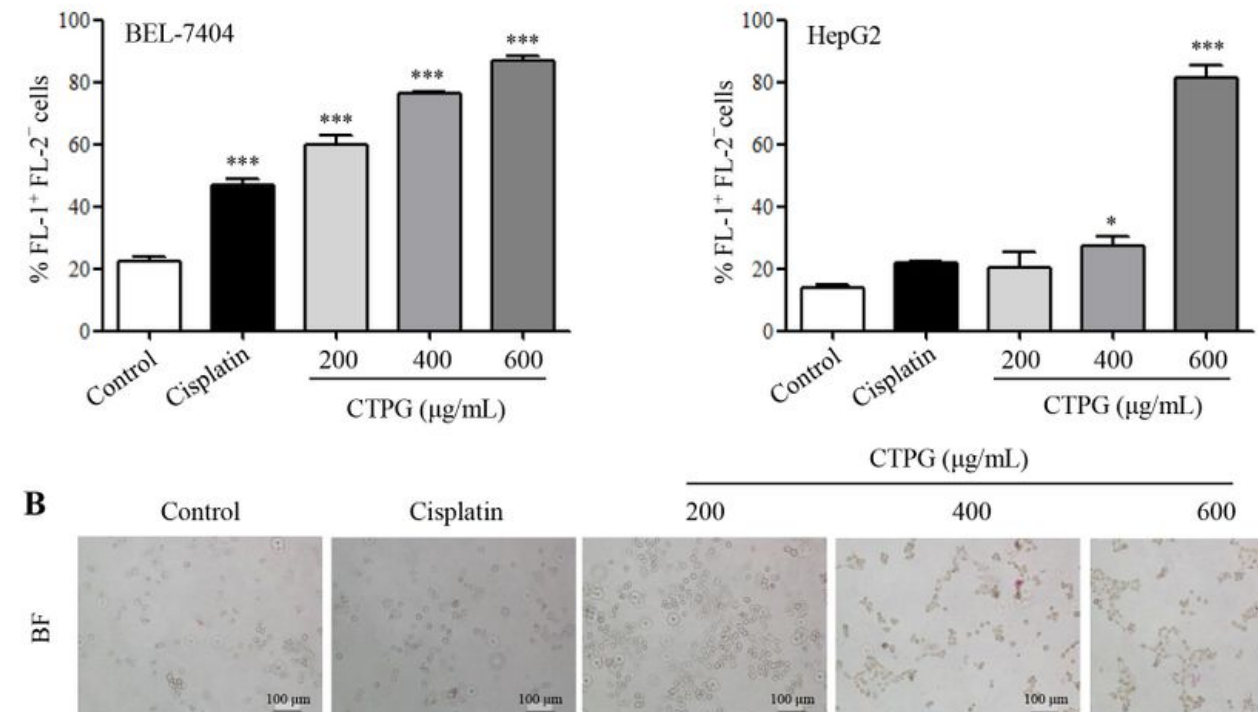

Cisplatin

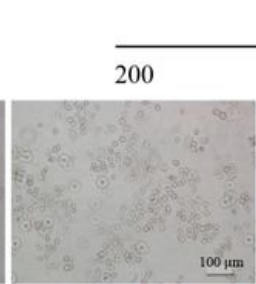

CTPG $(\mu \mathrm{g} / \mathrm{mL})$
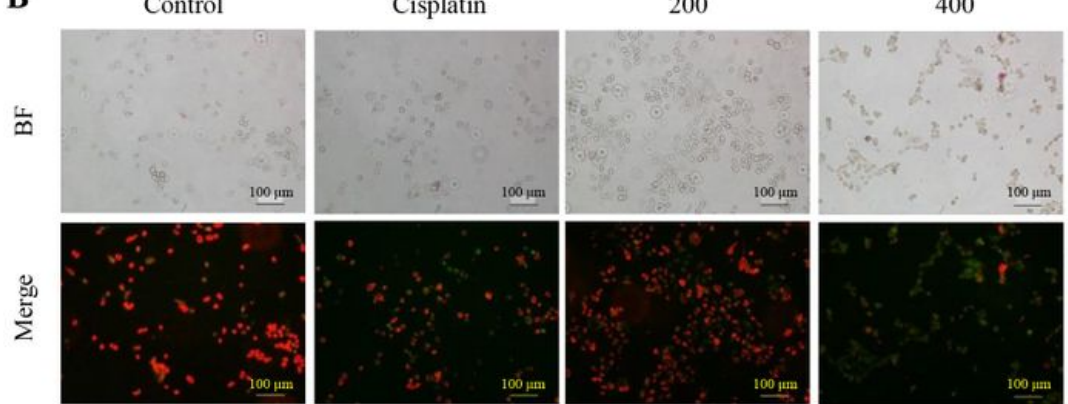

600
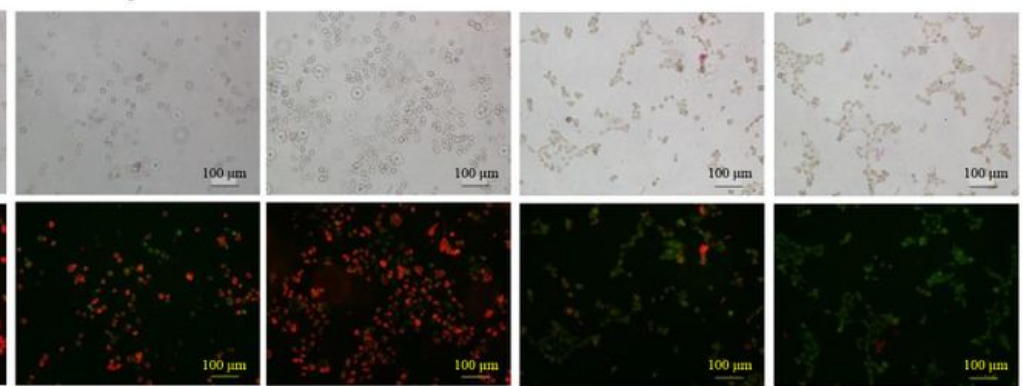

C

BEL-7404 CTPG $(\mu \mathrm{g} / \mathrm{mL})$
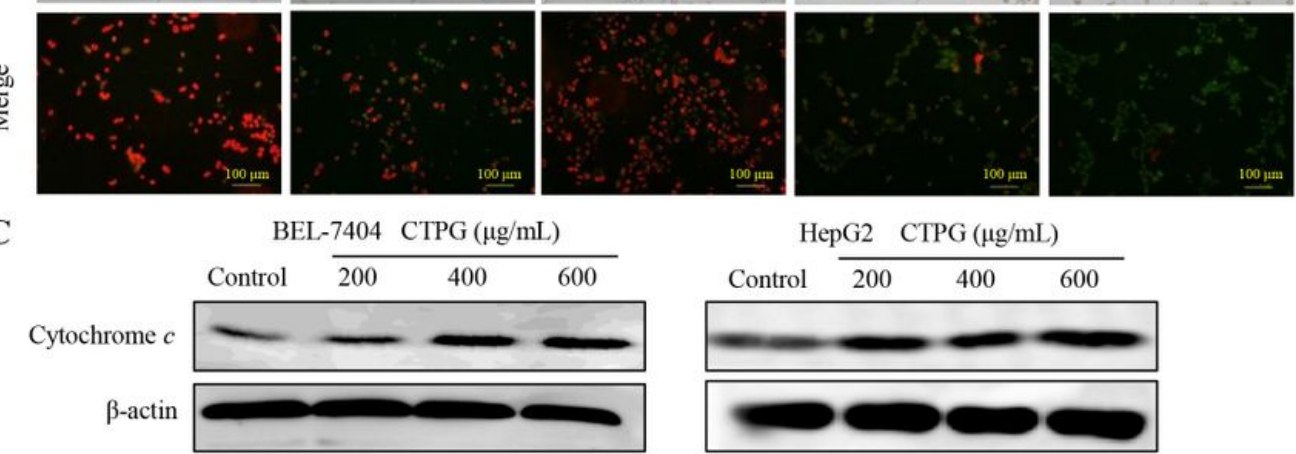

HepG2 CTPG $(\mu \mathrm{g} / \mathrm{mL})$

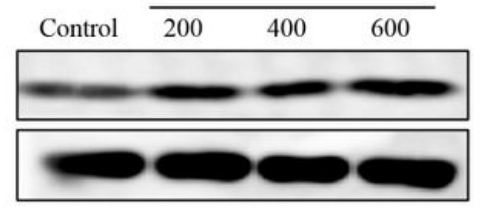

Figure 4

The effects of CTPG on $\triangle \psi m$ in HCC cells. BEL-7404 and HepG2 cells were treated with different concentrations (0, $200,400,600 \mu \mathrm{g} / \mathrm{mL}$ ) of CTPG. After $24 \mathrm{~h}$, cells were stained with JC-1 and the fluorescence changes were analyzed by flow cytometry $(A)$ and observed using inverted fluorescence microscopy $(B) .{ }^{*} p<0.05 ; * \star * p<0.001$ compared with control. (C) After $24 \mathrm{~h}$, proteins were isolated and the levels of cytochrome $\mathrm{c}$ were detected by Western blot. 

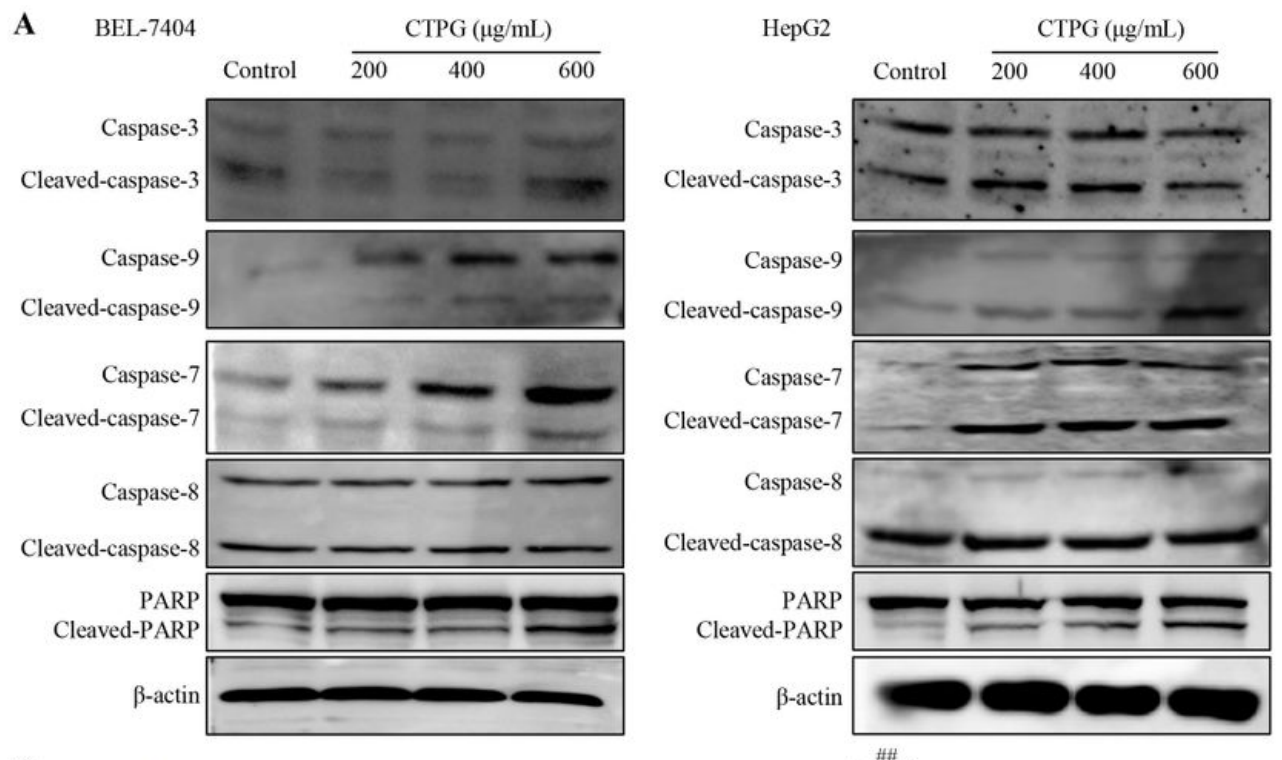

B
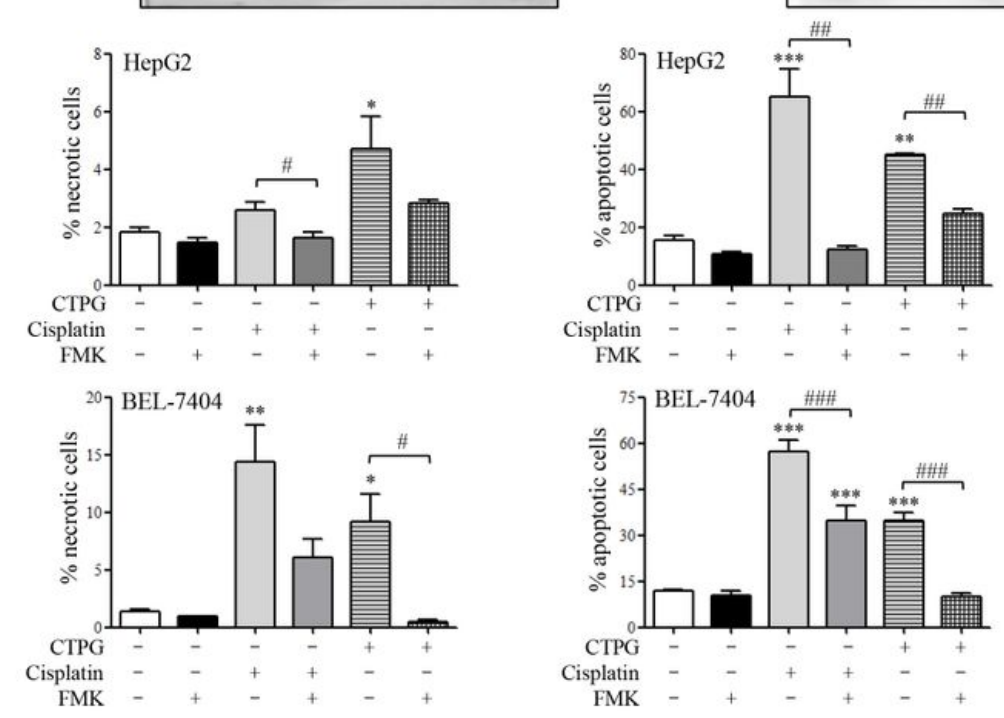

C
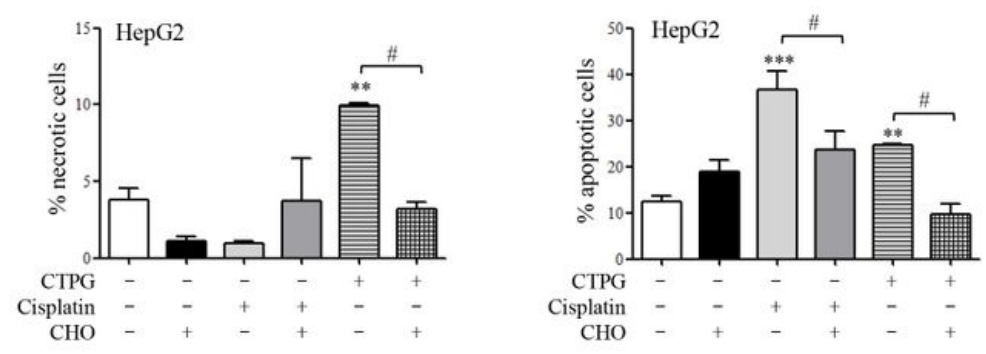

Figure 5

CTPG induced apoptosis in HCC cells via caspase pathway. (A) BEL-7404 and HepG2 cells were treated with different concentrations $(0,200,400,600 \mu \mathrm{g} / \mathrm{mL})$ of CTPG. After $24 \mathrm{~h}$, proteins were isolated and the levels of cleaved-caspases and -PARP were detected by Western blot. (B) BEL-7404 or HepG2 cells were treated with 400 $\mu \mathrm{g} / \mathrm{mL}$ CTPG in the absence or presence of caspase inhibitor (FMK) for $24 \mathrm{~h}$. (C) HepG2 cells were treated with 400 $\mu \mathrm{g} / \mathrm{mL}$ CTPG in the absence or presence of caspase-3 inhibitor $(\mathrm{CHO})$ for $24 \mathrm{~h}$. The necrotic and apoptotic BEL7404 or HepG2 cells were detected by flow cytometry. ${ }^{*} p<0.05 ;{ }^{*} p<0.01 ; * \star \star p<0.001$ compared with control. \# $p<0.05 ; \# \# p<0.01 ; \# \# \# p<0.001$ compared between samples with or without inhibitor. 

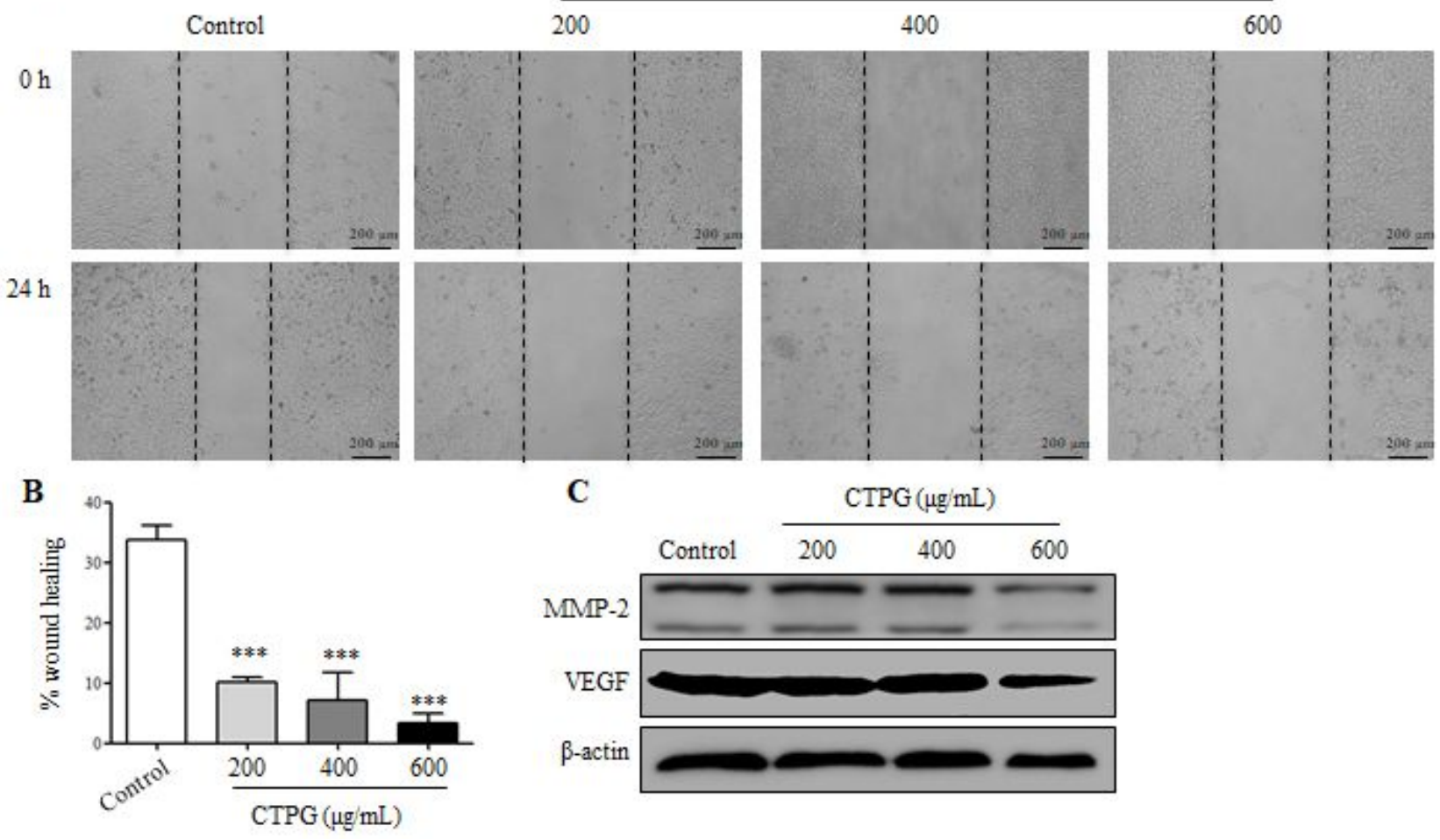

\section{Figure 6}

CTPG inhibited HCC cell migration in vitro. HepG2 cells were treated with different concentrations $(0,200,400,600$ $\mu \mathrm{g} / \mathrm{mL}$ ) of CTPG for $24 \mathrm{~h}$. HepG2 cell migration was observed by inverted microscope (A) and analyzed by Image $\mathrm{J}$ (B). ${ }^{* \star *} \mathrm{p}<0.001$ compared with control. (C) Proteins were isolated to detect the levels of MMP-2 and VEGF by Western blot. 
A

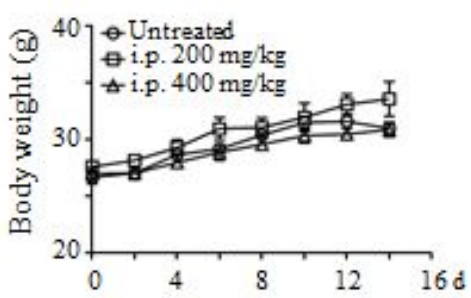

B
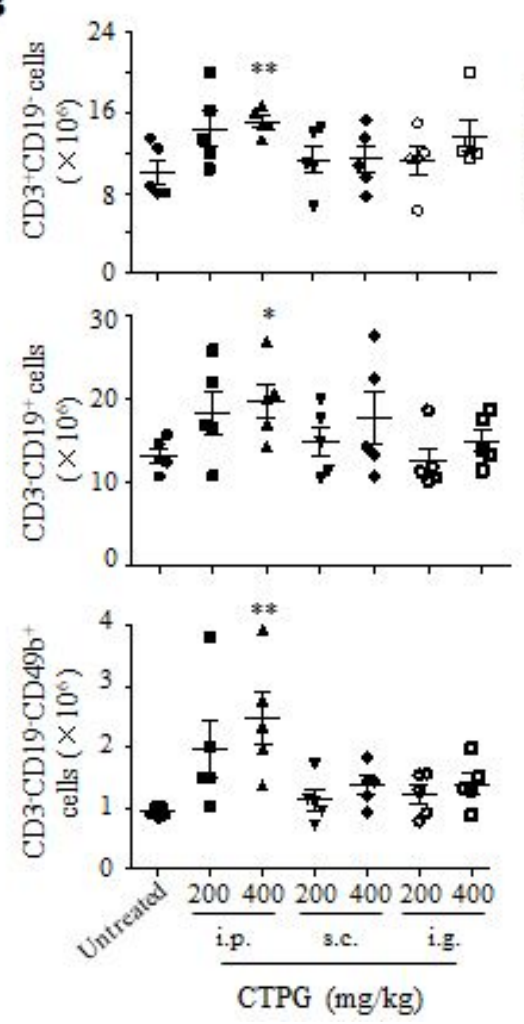
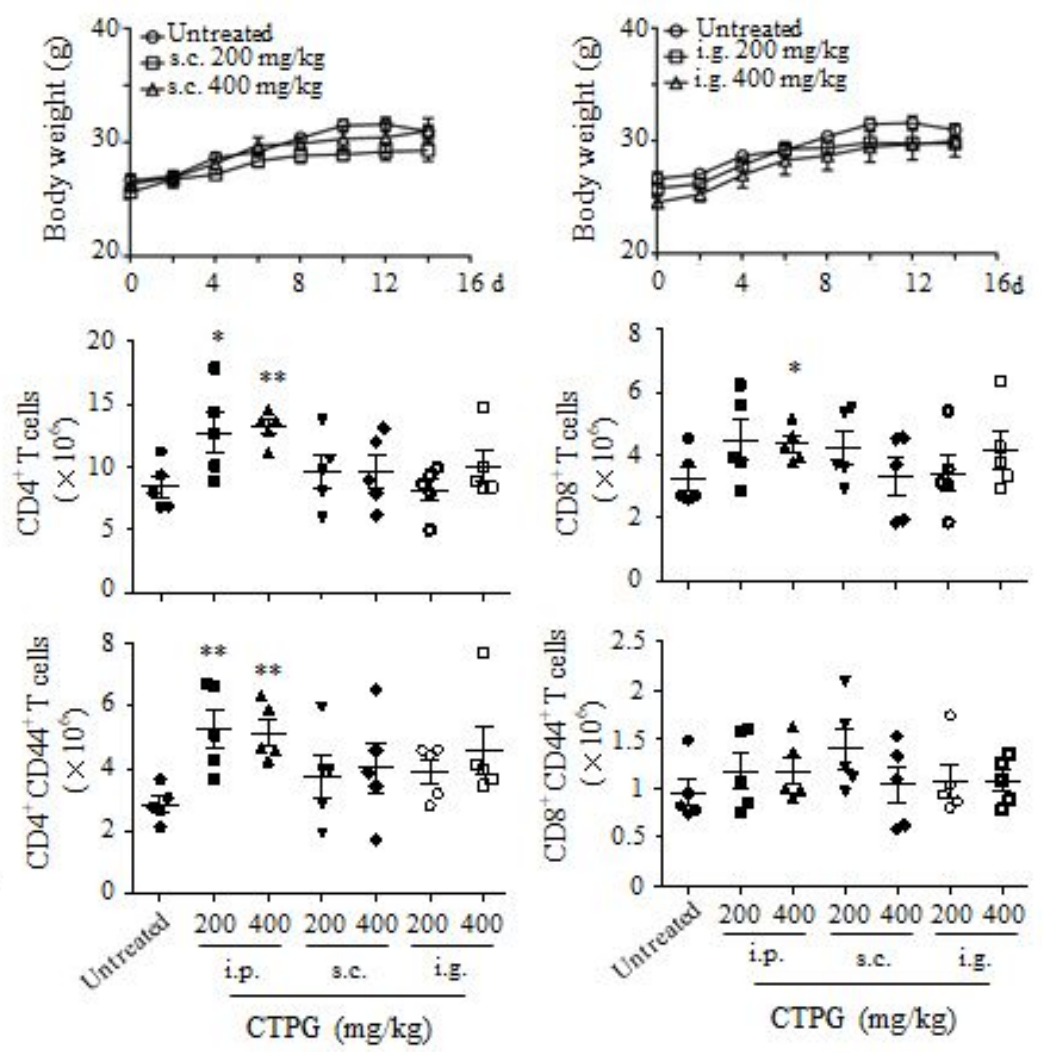

Figure 7

The effects of CTPG on immunity of mice. Mice were injected with different concentrations of CTPG through different administration. On day 15, mice were sacrificed to collect spleens. (A) Body weight of mice. (B) The cell numbers in spleens were calculated and the activation of CD4+ and CD8+ T cells was detected by flow cytometry. * $p<0.05$; ** $p<0.01$ compared with untreated group. 
A

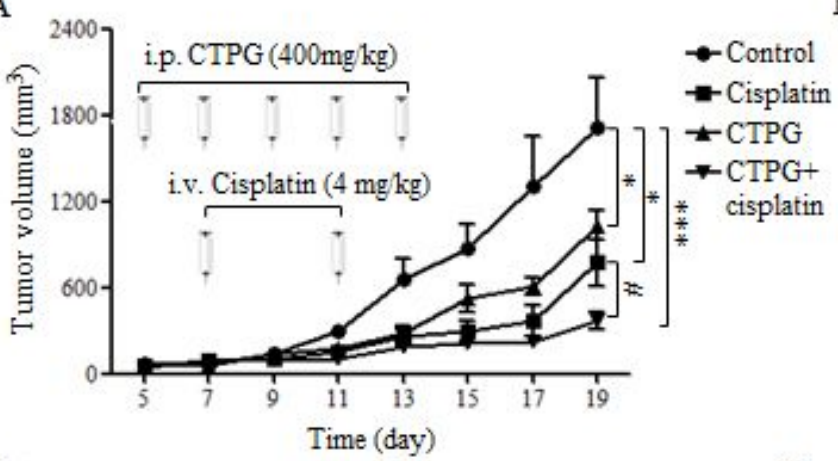

B

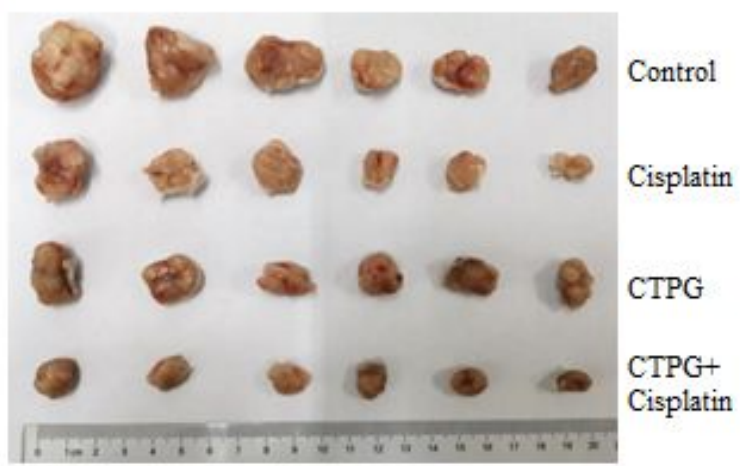

D

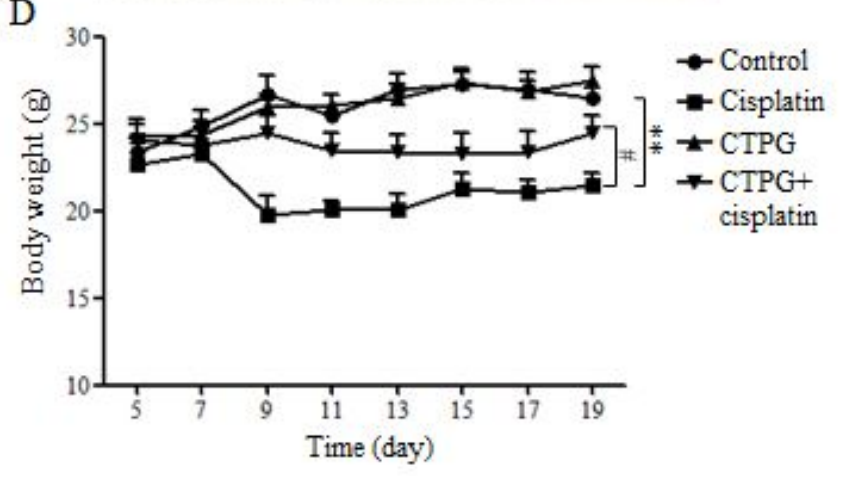

\section{Figure 8}

Antitumor efficacy of CTPG combined with cisplatin in H22 tumor mouse model. (A) Tumor volumes of mice. The syringe marks represent the day of injection. (B) Photographs of tumors in each group at the end of the experiment. (C) Tumor weight of each group at the end of the experiment. (D) Body weight of the mice over the entire experimental period from the day of injection. * $p<0.05$; ${ }^{\star \star \star} p<0.001$ compared with control group. \# $p<0.05$; \#\#\# $p<0.001$ compared between experimental groups. 
A

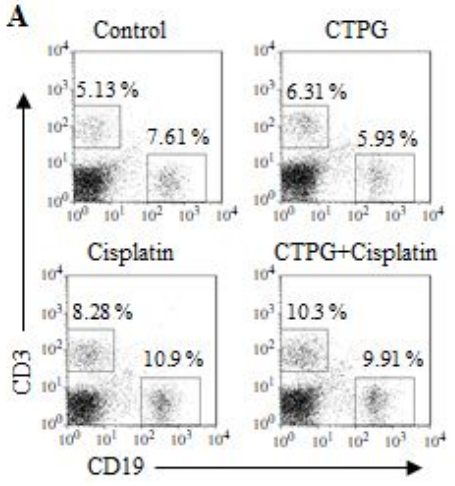

B

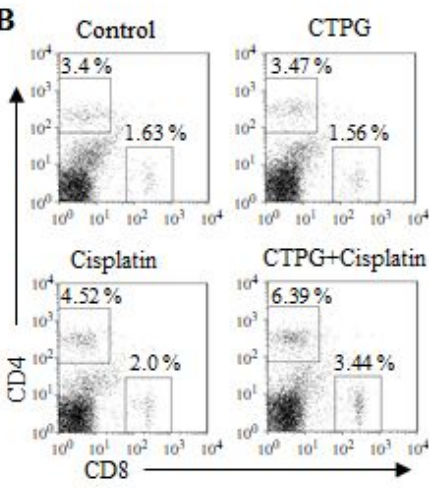

C

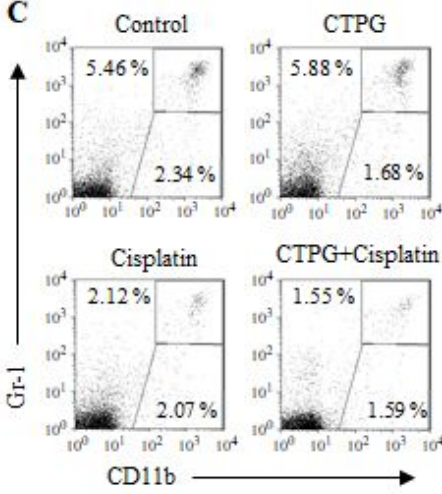

D

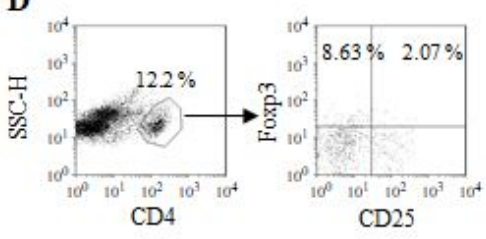

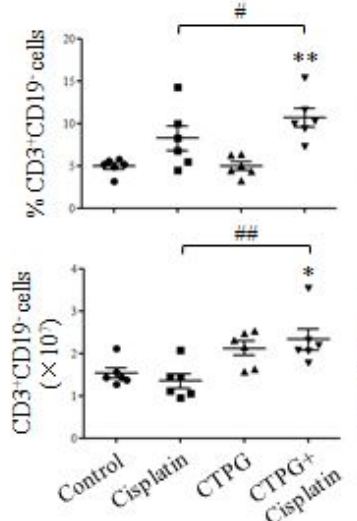
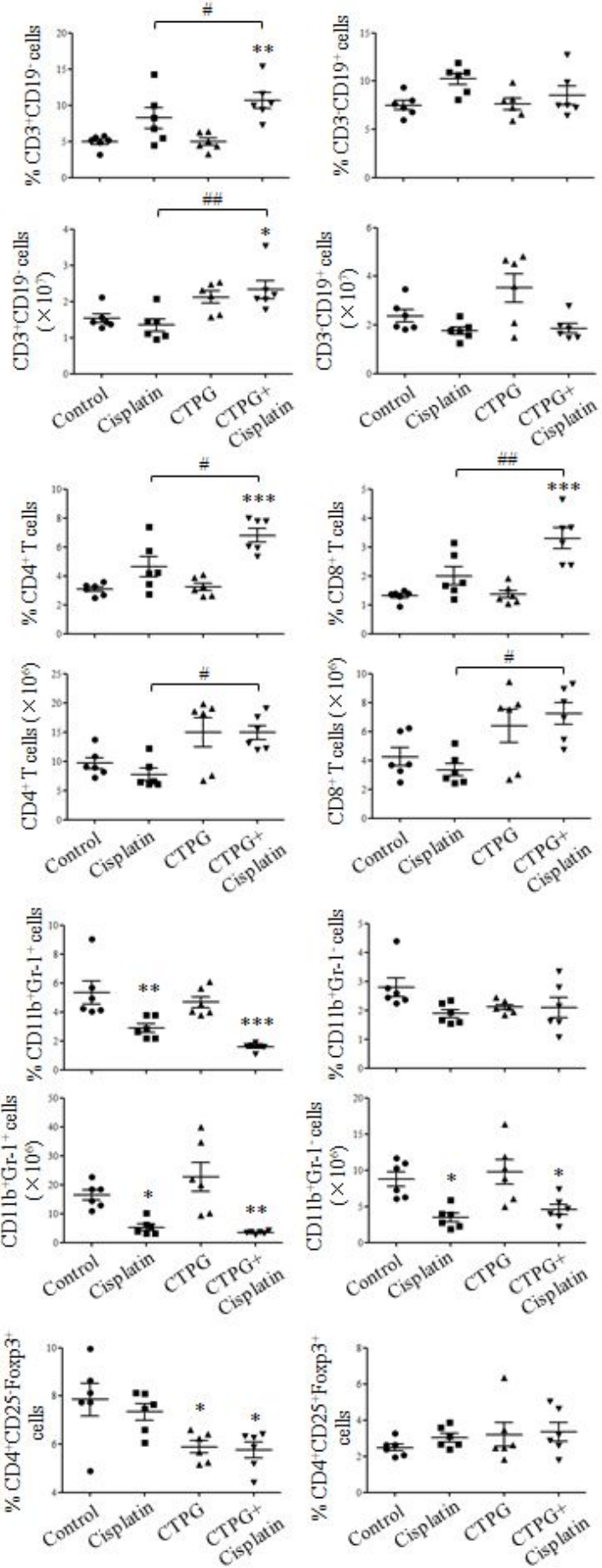

\section{Figure 9}

The effects of combined therapy on immunity of tumor mice. Spleens of tumor mice were isolated to detect the frequencies and numbers of immune cells at the end of experiment. (A) The frequencies and numbers of $T$ and $B$ cells. (B) The frequencies and numbers of CD4+ and CD8+ T cells. (C) The frequencies and numbers of MDSCs $(C D 11 b+G r-1+)$ and macrophages (CD11b+Gr-1-). (D) The frequencies of Tregs. * $p<0.05 ; * \star p<0.01 ; * \star * p<0.001$ compared with control group. \# $p<0.05$; \#\# $p<0.01$ compared between experimental groups.

\section{Supplementary Files}


This is a list of supplementary files associated with this preprint. Click to download.

- TumourmeasurementsAnimalweightsandTumourweights.docx

- Westernboltsinfigures.docx

- Graphicalabstract.jpg

- SupplementalFigure1.jpg

- SupplementalFigure2.jpg 